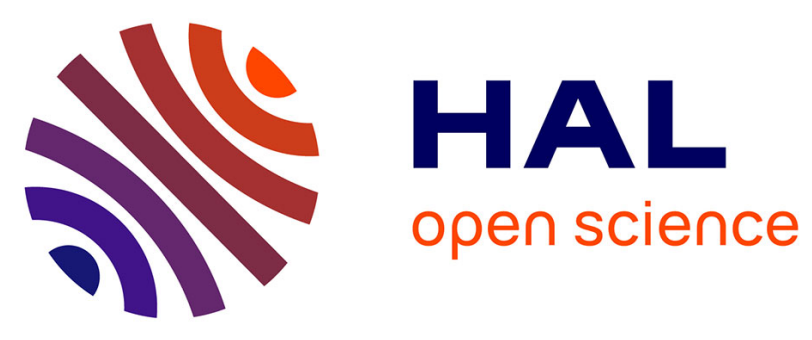

\title{
Iron Isotope Fractionation during Bio- and Photodegradation of Organoferric Colloids in Boreal Humic Waters
}

Olga Oleinikova, Franck Poitrasson, Olga Yu. Drozdova, Liudmila Shirokova, Sergey Lapitskiy, Oleg Pokrovsky

\section{To cite this version:}

Olga Oleinikova, Franck Poitrasson, Olga Yu. Drozdova, Liudmila Shirokova, Sergey Lapitskiy, et al.. Iron Isotope Fractionation during Bio- and Photodegradation of Organoferric Colloids in Boreal Humic Waters. Environmental Science and Technology, 2019, 53 (19), pp.11183-11194. 10.1021/acs.est.9b02797 . hal-02399037v2

\section{HAL Id: hal-02399037 \\ https://hal.science/hal-02399037v2}

Submitted on 30 Sep 2021

HAL is a multi-disciplinary open access archive for the deposit and dissemination of scientific research documents, whether they are published or not. The documents may come from teaching and research institutions in France or abroad, or from public or private research centers.
L'archive ouverte pluridisciplinaire HAL, est destinée au dépôt et à la diffusion de documents scientifiques de niveau recherche, publiés ou non, émanant des établissements d'enseignement et de recherche français ou étrangers, des laboratoires publics ou privés. 
Olga V. Oleinikova ${ }^{1}$, Franck PoItrasson ${ }^{1}$, Olga Yu. DrozdovA ${ }^{2}$, Liudmila S. SHIROKOVA ${ }^{1,3}$, Sergey A. LAPITSKIY ${ }^{2}$, and Oleg S. POKROVSKY ${ }^{1,3,4^{*}}$

${ }^{1}$ GET (Geosciences and Environment Toulouse) UMR 5563 CNRS, 14 Avenue Edouard Belin, 31400 Toulouse, France

${ }^{2}$ Geological Faculty of Moscow State University, 1 Leninskie Gory, 119234 Moscow, Russia

${ }^{3}$ N. Laverov Federal Center for Integrated Arctic Research, Russian Academy of Science, 23

Naberezhnaya Sev Dviny, Arkhangelsk, Russia

${ }^{4}$ BIO-GEO-CLIM Laboratory, Tomsk State University, 36 Lenina av., 634050 Tomsk, Russia

* Corresponding author. Email address: oleg.pokrovsky@get.omp.eu (Oleg S. Pokrovsky).

Key words: Fe, heterotrophic bacteria, photolysis, sunlight, Arctic, organic carbon, complexation, size fractionation, oxidation, precipitation

Submitted to Environ Sci Technol after revision, September 2019

25 Key messages:

26 Adsorption of heavy Fe isotopes on heterotrophic bacteria cell surface

27 Assimilation of light Fe isotopes by live P. aureofaciens cells

28 Removal of heavy Fe isotopes from solution during sunlight oxidation of organo-ferric colloids

29 Generation of isotopically light $\mathrm{Fe}(\mathrm{II})$ in $\mathrm{LMW}_{<1 \mathrm{kDa}}$ during photolysis

30 Bio-and photodegradation of organo-ferric colloids can produce very large, from -2.5 to $+3.2 \%$

$31 \quad \delta^{57} \mathrm{Fe}$ isotopic variations in boreal waters 


\section{ABSTRACT}

Bio-degradation and photolysis of dissolved organic matter (DOM) in boreal high-latitude waters are the two main factors controlling aquatic fluxes and residence time of carbon but also metal nutrients associated with DOM such as Fe. The DOM is usually present in the form of organic and organo-mineral colloids that also account for the majority of dissolved Fe. Here we use the stable Fe isotope approach to unravel the processes controlling Fe behavior during bio- and photo-degradation of colloids in boreal Fe- and DOM-rich humic waters (a stream and a fen). The adsorption of Fe

48 colloids onto heterotrophic bacteria $P$. aureofaciens produced enrichment in $+0.4 \%$ ( $\left(\delta^{57} \mathrm{Fe}\right)$ in the

49 heavier isotopes of the cell surface relative to the remaining solution. In contrast, long-term 50 assimilation of Fe by live cells yielded preferential incorporation of lighter isotopes into the cells ($0.7 \%$ relative to aqueous solution). The sunlight-induced oxidation of $\mathrm{Fe}(\mathrm{II})$ in fen water led to 52 removal of heavier Fe isotopes $(+1.5$ to $+2.5 \%$ ) from solution, consistent with Fe(III) hydroxide 53 precipitation from Fe(II)-bearing solution. Altogether, bio- and photodegradation of organo-ferric 54 colloids, occurring within a few days of exposure time, can produce several per mil isotopic 55 excursions in shallow lentic and lothic inland waters of high latitude boreal regions. Considerable 56 daily scale variations of Fe isotopic composition should therefore be taken into account during 57 interpretation of riverine flux of $\mathrm{Fe}$ isotope to the ocean or tracing weathering processes using $\mathrm{Fe}$ 58 isotopes in surface waters at high latitudes.

\section{Introduction}

Despite broad use of Fe isotopes for tracing various large-scale, long-term processes at the Earth's surface ${ }^{1,2}$, notably in river $^{3-8}$ or lake ${ }^{9,10}$ waters, the fractionation of $\mathrm{Fe}$ isotopes during shortterm processes such as bio- and photo-degradation of organic matter that binds Fe in freshwater

64 remain poorly understood. This is especially true for organic carbon and Fe-rich boreal waters, that,

65 from the one hand, play a primary role in the $\mathrm{C}$ cycle, $\mathrm{CO}_{2}$ emissions and storage ${ }^{11}$ and from the 
other hand, strongly contribute to Fe and other micro-nutrient export by rivers to the coastal

67 productive zones ${ }^{13,14}$.

The majority of dissolved $(<0.22 \mu \mathrm{m}) \mathrm{Fe}$ and other metals in boreal waters are present in the

69 form of organic and organo-mineral colloids $(1 \mathrm{~nm}-0.22 \mu \mathrm{m})$ whose transport and bioavailability

70 differ from inorganic ions or simple organic complexes ${ }^{15}$. Two main processes responsible for fluxes

71 and residence time of organic $\mathrm{C}$ and metal colloids in boreal high-latitude aquatic environments are

72 heterotrophic bacterial respiration (degradation of DOM) and photolysis ${ }^{16}$. Colloidal transformation

73 often occurs along the hydrological continuum of interconnected soil waters, mires, streams and

74 large oligotrophic lakes ${ }^{17}$. Under the action of aquatic microorganisms and sunlight irradiation, the

75 organic and organo-ferric colloids are subjected to change of dominant source and molecular weight

76 from allochthonous large-size humic and fulvic molecules to small size autochthonous organic

77 ligands ${ }^{17}$. Further, the DOC can be degraded into $\mathrm{CO}_{2}$ or taken up by heterotrophic bacterioplankton.

78 This may liberate $\mathrm{Fe}(\mathrm{III})$ ions, leading to $\mathrm{Fe}$ oxy(hydr)oxide precipitation ${ }^{18,19}$. Finally,

79 photooxidation of DOM may lead to enrichment in low molecular weight organic ligands and their

80 complexes with metals ${ }^{20}$.

81 In contrast to numerous works devoted to microbiological ${ }^{21}$ and photochemical $^{22}$

82 mineralization of dissolved organic carbon (DOC), nitrogen and phosphorus, the bacterial and

83 sunlight-induced transformations of Fe-rich colloids in inland waters have been little studied ${ }^{23,24}$. The

84 transformation of colloidal Fe in boreal waters, including bogs, lakes and rivers ${ }^{25}$ has been studied

85 under the metabolic action of heterotrophic soil and aquatic bacteria ${ }^{18,26-27}$ and sunlight ${ }^{28}$. In these

86 works we demonstrated that the biodegradation of organo-ferric colloids by heterotrophic bacteria

87 consists of $i$ ) element uptake inside the cells; ii) element adsorption at the cell surface, and iii) $\mathrm{Fe}$

88 hydroxide precipitation leading to scavenging of associated trace metals. During both biodegradation

89 and photolysis of natural DOM, Fe plays a pivotal role in controlling the fate of trace elements (TE).

90 This control occurs via $i$ ) formation of insoluble Fe(III) hydroxides that coprecipitate other trace 
91 metals $^{28}$, and ii) generation of low molecular weight (LMW) organic ligands that bind Fe, thus

92 competing with strong organic complexes of other metals ${ }^{19,20,28}$.

The Fe isotope approach is an efficient tool for deciphering elementary processes involving 94 microbes and aqueous solutions ${ }^{29-33}, \mathrm{DOM}-\mathrm{Fe}^{34}$ and mineral $-\mathrm{Fe}^{35,36}$ interaction including 95 colloids $3,6,37$. The latter study demonstrated an unusual enrichment of heavier Fe isotopes in the LMW $\left(<1-10 \mathrm{kDa}\right.$ ) fraction relative to remaining colloidal fraction (by up to +3 to $+4 \%$ in $\delta^{57} \mathrm{Fe}$ )

97 and suggested that bio- and/or photo-transformation of colloids may be responsible for heavy $\mathrm{Fe}$ 98 isotope signatures in LMW fraction of boreal waters. However, the photo-oxidation of organo-ferric 99 colloids removes $\mathrm{Fe}$ in the form of Fe(III) hydroxides ${ }^{19,23,38}$ which can enrich the remaining solution 100 in lighter $\mathrm{Fe}$ isotopes, consistent with numerous laboratory experiments on $\mathrm{Fe}$ hydroxide 101 precipitation from $\mathrm{Fe}(\mathrm{II})$-bearing aqueous solution ${ }^{39}$. Whereas for $\mathrm{Fe}^{3+}(\mathrm{aq}) \rightarrow \mathrm{Fe}(\mathrm{III})_{\text {solid }}$ (hematite) 102 reaction at equilibrium, a negligible fractionation of $-0.15 \pm 0.30 \%\left(\Delta^{57} \mathrm{Fe}\right)$ was reported ${ }^{40}$, the $103 \mathrm{Fe}^{2+}(\mathrm{aq}) \rightarrow \mathrm{Fe}(\mathrm{III})_{\text {solid }}$ (ferrihydrite) reaction has $\Delta^{57} \mathrm{Fe}$ of $+4.8 \pm 0.15 \%{ }^{39}$. Other experiments 104 producing goethite reported a fractionation factor of $+1.7 \pm 0.14 \%$, corresponding to the $\mathrm{Fe}(\mathrm{III})_{\text {solid }}$ 105 being enriched in heavier isotopes ${ }^{41}$. As for the bacterially-induced colloid transformation, two main 106 processes controlling the isotope fractionation during metal-live cell interaction are 1) fast adsorption 107 of heavier Fe isotope on the cell surfaces ${ }^{30,31}$, and 2) long-term assimilation of heavier Fe isotopes as 108 recently shown for phytoplankton ${ }^{42}$ and magnetotactic bacteria ${ }^{33}$. Note however that, in contrast to 109 the fairly good knowledge of isotope fractionation of ionic metals and their organic complexes 110 interaction with microbial cells, virtually nothing is known on colloidal metal - cell interaction 111 reactions. The present study is aimed at the quantification of Fe isotope signatures during photo- and 112 bio-degradation of DOM-Fe complexes in high latitude boreal waters. We hypothesized preferential 113 removal of heavier $\mathrm{Fe}$ isotopes by live cell adsorption and assimilation and $\mathrm{Fe}$ hydroxide 114 precipitation in the course of bio- and photodegradation of organo-ferric colloids. We further tested 115 the possibility of formation of isotopically heavy Fe in $\mathrm{LMW}_{<1 \mathrm{kDa}}$ fraction of river waters, as it was 116 put forward in a previous study ${ }^{37}$. To test these hypotheses, we selected a stream and a fen water, two 
117 dominant types of Fe-rich freshwaters of the subarctic. By choosing two main processes controlling

118 the fate of organo-ferric colloids (bio- and photo-degradation) and two representative examples of

119 boreal Fe- and DOM-rich surface waters, we were capable to reveal the main factors that govern Fe

120 isotope behavior on a short-term (daily) scale in large territory of subarctic landscapes.

121 2. Materials and methods

The surface waters were collected in the Northern Karelia region (NW Russia). The climate

123 of the region is mild-cold, transitional between oceanic and continental. Average temperature in

124 January is $-13{ }^{\circ} \mathrm{C}$, and $+15{ }^{\circ} \mathrm{C}$ in July; average annual precipitation ranges between 450 and 550

$125 \mathrm{~mm} \mathrm{y}^{-1}$. Our study area is in the most elevated part of Karelia, within a landscape of tectonic

126 denudation hills, plateaus and ridges with an average altitude of 300-400 m, with separate insulated

127 massifs. Predominant soils are illuvial-humic and illuvial-ferruginous-humic podzols. Coniferous

128 forest (pine and spruce) with some deciduous trees (birch, aspen and alder) dominates the

129 vegetation of the region. Further landscape setting is described in previous works of our group ${ }^{17,37}$.

130 Within the hydrological continuum created by glacial processes around 8-10 thousand years ago,

131 the water and soluble compounds travel from the ombrotrophic peat mire zone downstream the

132 river towards a large oligotrophic lake. At the lake coast, there are minerotrophic fens located in

133 depressions that receive their water via shallow groundwater and soil flux ${ }^{43}$.

134 A small stream and a coastal fen were collected in July 2015, during summer baseflow

135 period. The Palojoki stream (watershed area $=32 \mathrm{~km}^{2}$, bedrock of granites, gneisses, syenites, and

136 syenite-diorites of the early-Proterozoic and late-Archean, covered by glacial Quaternary deposits

137 under podzol soils ${ }^{43}$ ) was sampled in the middle course of the flow (sample KAR-1 ${ }^{17}$ ). The fen

138 adjacent to the western coast of the Tsipringa Lake had an area of $1.19 \mathrm{~km}^{2}$ and is underlain by

139 Early-Archean biotite granito-gneisses (sample ZPBL ${ }^{17}$ ).

140 The experiments included on-site photodegradation of sterile-filtered $(<0.22 \mu \mathrm{m})$ stream and

141 fen water in quartz reactors and laboratory microcosm experiments in the presence of $1 \mathrm{~g}_{\text {wet }} / \mathrm{L}$ of

142 Pseudomonas aureofaciens, highly abundant culturable bacteria isolated form podzol soils ${ }^{44}$. The 
143 experimental scheme described in previous works from our group ${ }^{27,28}$ is shown in Fig. 1. The 144 biodegradation experiments with stream and fen waters were performed after 6 months storage of 145 sterile-filtered samples in the refrigerator. Freshly-collected bacteria at the stationary growth stage 146 were rinsed in $0.85 \% \mathrm{NaCl}$ and allowed to starve in nutrient-free $0.85 \% \mathrm{NaCl}$ solution during 5 days. 147 The cells were rinsed again 3 times before the experiment, concentrated in a mother suspension and 148 added to sterile, acid-washed polypropylene flasks with stream or fen water (typically $2 \mathrm{~mL}$ of 149 bacterial suspension to $200 \mathrm{~mL}$ of water) to provide the wet biomass concentration of $1 \mathrm{~g}_{\mathrm{wet}} \mathrm{L}^{-1}$. Note 150 that the amount of $\mathrm{Fe}$ originated from bacteria addition does not exceed $1 \mu \mathrm{g} \mathrm{L}^{-1}$ for this 151 concentration of biomass ${ }^{27}$. The flasks were shaken at $25 \pm 0.5^{\circ} \mathrm{C}$ and aerated via Biosilico ${ }^{\circledR}$ 152 ventilation porous caps during 4 days. Aliquots of homogeneous suspension were sampled after 0,1 , $1538,22,30,50$ and $100 \mathrm{~h}$ after the addition of bacteria and filtered through $0.22 \mu \mathrm{m}$ membrane. All the 154 biodegradation experiments were run in duplicates. The control experiment was sterile filtered $(<$ $1550.22 \mu \mathrm{m})$ biomass-free stream and fen water and it was processed exactly as bacterial samples.

156 For photo-degradation experiments, the stream and fen waters were collected in pre-cleaned 157 polypropylene jars and stored in dark cold place $\left(6 \pm 2^{\circ} \mathrm{C}\right)$ prior the experiments. The waters were 158 processed on-site, within $2 \mathrm{~h}$ after sampling, in the field-constructed clean laboratory ${ }^{37}$. Sterile 159 filtration was performed using single-used Sartorius polystyrene vacuum filtration units $(0.22 \mu \mathrm{m}$, $160250 \mathrm{~mL}$ volume). Filtered fluids were transferred into $270-\mathrm{mL}$ sterilized quartz flasks, filled with $16110 \%$ air headspace and covered by porous sterile stoppers. The dark control of quartz flasks was 162 identical to the light samples except that the reactors were wrapped in Al foil. Both dark and light 163 reactors were run in duplicates and they were placed on flat surface at the border of the lake $164\left(66^{\circ} 17^{\prime} 04^{\prime \prime} \mathrm{N}, 30^{\circ} 52^{\prime} 05^{\prime \prime} \mathrm{E}\right)$. The flasks were exposed to direct unshaded sunlight from July 9 to July 16520 during essentially anticyclonic weather. The daytime duration in this period was between 22 and 16620.5 hours. The temperature of the experimental reactors followed the diurnal cycle and was equal to $16718 \pm 5^{\circ} \mathrm{C}$ over $250 \mathrm{~h}$ of exposure, which was within the range of actual water temperature in stream 168 and fen during the month of July ${ }^{17,37}$. The quartz reactors were sampled after 0,100 and $200 \mathrm{~h}$ of 
169 exposure of the fen water (ZPBL) and after 0,110 and $250 \mathrm{~h}$ of exposure of the stream (KAR-1). For 170 each sampling, the whole reactor was sacrificed. The samples were immediately filtered through 0.22 $171 \mu \mathrm{m}$ Sartorius single-used filter into pre-cleaned polypropylene vials. These waters were then 172 acidified using bi-distilled $\mathrm{HNO}_{3}$ for trace metals analysis or directly used, without acidification, for 173 DOC, $\mathrm{UV}_{254} \mathrm{~nm}$, DIC and anions determinations. The $0.22 \mu \mathrm{m}$ filtrate from quartz reactors was 174 additionally ultrafiltered through 1 and $10 \mathrm{kDa}$ regenerated cellulose single-use filters with an 175 Amicon 8400 frontal Ultrafiltration unit (continuously stirred 400-ml polycarbonate cell maintained 176 under 1.5-2 atm pressure). Details of ultrafiltration procedure in humic boreal waters of North 177 Karelia and discussion of possible artifacts are presented elsewhere ${ }^{17,37,43}$. In these experiments, we 178 consider the behavior of $\mathrm{Fe}$ in $<0.22 \mu \mathrm{m}$ and $<10 \mathrm{kDa}$ fractions of the stream water and in $<0.22 \mu \mathrm{m}$, $179<10$ and $<1 \mathrm{kDa}$ fractions of the fen water.

180 Analyses of DOC and Fe concentration in various filtered and ultrafiltered fractions were 181 performed using Shimadzu TOC-VCSN and Agilent ICP MS, following procedures described 182 previously ${ }^{27,28}$. The DOC was measured with an uncertainty of $3 \%$ and a detection limit of $0.1 \mathrm{mg} \mathrm{L}^{-}$ 183 1. The total dissolved Fe represents the sum of Fe(II) and Fe(III) in the $<0.22 \mu \mathrm{m}$ fraction. The 184 uncertainty of Fe concentration measurements ranged from 5 to $10 \%$ (1SD). The international 185 geostandard SLRS-5 (Riverine Water Reference Material for Trace Metals certified by the National 186 Research Council of Canada) measured each 20 samples was used to check the validity and 187 reproducibility of Fe analysis. Good agreements were found between the replicate measurements of 188 Fe in SLRS-5 and the certified values (relative difference $<20 \%$ SD on the repeated measurements). Assessment of $\mathrm{Fe}(\mathrm{II})$ and $\mathrm{Fe}(\mathrm{III})$ concentrations was performed using the conventional 190 ferrozine method ${ }^{45}$. The efficiency of this method in organic-rich tropical waters was further 191 demonstrated in Rio Negro ${ }^{46}$. Because of possible interferences from DOM in humic boreal waters, 192 the ferrozine method was used employing a standard addition technique. This allowed to achieve a 193 detection limit of $15 \mu \mathrm{g} \mathrm{L}^{-1}$ and an uncertainty from $10-20 \%$ at $15<\mathrm{Fe}$ (II) $<100 \mu \mathrm{g} \mathrm{L}^{-1}$ to $5-10 \%$ at $194 \mathrm{Fe}(\mathrm{II})>100 \mu \mathrm{g} \mathrm{L}^{-1}$. Further, we verified the stability of $\mathrm{Fe}(\mathrm{II})$ in oxygenated humic waters $(\mathrm{pH}=4.6$ 
to 6.5 ; DOC $=20$ to $50 \mathrm{mg} \mathrm{L}^{-1}$ ) using peat and moss leachate (similar to main allochthonous DOM in

196 studied sites ${ }^{47}$ ). The Fe(II) concentration remained stable within $\pm 10 \%$ over $24-180 \mathrm{~h}$ of exposure.

The $\mathrm{Fe}(\mathrm{III})$ and $\mathrm{Fe}(\mathrm{II})$ complexation with organic ligands and solution saturation degree with

198 respect to secondary Fe hydroxide in the course of experiment were calculated using Visual 199 MINTEQ $^{48}$, in conjunction with a NICA-Donnan humic ion bonding model, as described 200 previously ${ }^{17}$. We considered carboxylic and phenolic complexes of fulvic acids with $\mathrm{Fe}^{2+}$ and $\mathrm{Fe}^{3+}$ 201 ions, as well as $\mathrm{Fe}(\mathrm{II})$ weak (electrostatic) interaction with fulvic acids.

For Fe isotope analysis, filtered and acidified water samples were evaporated in the clean laboratory. After acid digestion of the residue using a mixture of $\mathrm{HCl}$ and $\mathrm{HNO}_{3}, \mathrm{Fe}$ was purified via anion exchange chromatography with $\mathrm{HCl}$ using Bio Rad AG1 X4 resin, 200-400 mesh to remove all matrix elements ${ }^{37}$. For this, we used thermoretractable Teflon columns with an internal diameter of $4 \mathrm{~mm}^{8}$. The resins were conditioned using $6 \mathrm{M}$ of $\mathrm{HCl}$ prior to the sample loading in $0.5 \mathrm{ml}$ of 6 $\mathrm{M} \mathrm{HCl}$. The matrix species were eluted in $3 \mathrm{ml}$ of the same acid and, subsequently, Fe was quantitatively eluted with $2 \mathrm{ml}$ of $0.05 \mathrm{M} \mathrm{HCl}$. The purified Fe solutions were evaporated at $120^{\circ} \mathrm{C}$. After evaporation, purified Fe samples were redissolved in a $0.05 \mathrm{M} \mathrm{HCl}$ solution that was used for

211 signals of ca. $40 \mathrm{~V}$ of ${ }^{56} \mathrm{Fe}$ and $20 \mathrm{~V}$ for ${ }^{60} \mathrm{Ni}$. Iron isotope measurements were performed at the 212 CNRS-INSU National MC-ICP-MS facility in Lyon using a Thermo Electron Neptune Plus and at 213 GET-CNRS in Toulouse using a Thermo Electron Neptune MC-ICP-MS (Bremen, Germany) ${ }^{49}$. All 214 analyses are reported in the delta notation relative to the IRMM-014 standard, expressed as $\delta^{57} \mathrm{Fe}$, 215 which represents the deviation in per mil relative to the reference material:

$$
\delta^{57} \mathrm{Fe}(\%)=\left(\frac{\left({ }^{57} \mathrm{Fe} /{ }^{54} \mathrm{Fe}\right)_{\text {sample }}}{\left({ }^{57} \mathrm{Fe} /{ }^{54} \mathrm{Fe}\right)_{\text {IRMM } 14}}-1\right) * 1000
$$

218 samples plot on a single mass fractionation line $\left(\delta^{57} \mathrm{Fe}=1.466 \times \delta^{57} \mathrm{Fe}+0.005, \mathrm{R}^{2}=0.9995, \mathrm{p}<\right.$ 219 $10^{-4}$ ), only $\delta^{57} \mathrm{Fe}$ values are discussed in this paper. Data quality was checked by the analysis of our 
220 in-house hematite standard every 5 samples in the analytical sequence. Our mean value of $2210.771 \pm 0.047 \%$ o (2SD) for this standard obtained between Lyon and Toulouse from pooling 51 222 individual analyses by groups of 6 was consistent with the values of $0.766 \pm 0.072 \%$ reported 223 previously $^{8}$.

3. Results and Discussion

\subsection{Iron in the $<0.22 \mu m$ fraction during biodegradation experiments: Heavier isotopes} adsorption onto and lighter isotopes uptake by live cells of P. aureofaciens

The studied surface waters were oxygenated, organic- and Fe-rich $(\mathrm{pH}=7.1, \mathrm{DOC}=12 \mathrm{mg}$ $\mathrm{L}^{-1}, \mathrm{Fe}=208 \mu \mathrm{g} \mathrm{L}^{-1}$ in KAR-1; $\mathrm{pH}=5.4, \mathrm{DOC}=38.7 \mathrm{mg} \mathrm{L}^{-1}$, and $\mathrm{Fe}=4310 \mu \mathrm{g} \mathrm{L}^{-1}$ in $\left.\mathrm{ZPBL}\right)$. The stream water contained $\sim 24 \%$ of $\mathrm{Fe}(\mathrm{II})$ and the fen contained $\sim 20 \%$ of $\mathrm{Fe}(\mathrm{II})$; the $\mathrm{LMW}_{<1 \mathrm{kDa}}$ fraction of DOC was sizably higher in the stream compared to the fen ( 77 and $29 \%$, respectively).

The experimental results are reported in Table 1 whereas those of the control experiments are listed in Table S1. The pH value increased by 0.6 and 1.2 unit over 4 days of $P$. aureofaciens reaction with stream water and fen water, respectively (Table 1). There was no sizeable DOC decrease over the first $1 \mathrm{~h}$ of reaction. The long-term removal $(1-100 \mathrm{~h})$ of DOC by $P$. aureofaciens was not pronounced in the stream water but was high in the fen water $(-33 \pm 5 \%)$.

Iron exhibited initial adsorption after $1 \mathrm{~h}$ of reaction as it is seen from the difference between the stream and the fen water control and bacterial suspension at the beginning of experiment (Fig. 2 $A$ and $B$ and Table 1). The proportions of fast adsorption (0-1 h) and intracellular assimilation/Fe(III) hydroxide $(1-93 \mathrm{~h})$ relative to total Fe removal in the experiments were respectively equal to $35 \%$ and $37 \%$ in the stream water and $30 \%$ and $25 \%$ in the fen water. In the latter, the concentration of divalent Fe decreased almost 3-fold over the first day of reaction relative

$244 \mathrm{Fe}(\mathrm{II})$ concentration in KAR-1 (not shown) was $30 \pm 20 \mu \mathrm{g} / \mathrm{L}(\sim 16 \%$ of total dissolved Fe), with a quantification limit of $\mathrm{Fe}(\mathrm{II})$ by this method of $15 \mu \mathrm{g} / \mathrm{L}^{45}$. 
All initial solutions were undersaturated with respect to Fe-bearing minerals. Calculated change of $\mathrm{Fe}(\mathrm{II})$ and $\mathrm{Fe}(\mathrm{III})$ speciation in the course of experiments demonstrated the dominance of 248 Fe(III)-fulvic acid (FA) complexes. The Fe(II) bound to FA fully disappeared in the stream and 249 decreased by a factor of 3 in the fen waters (Fig. S1). Specifically, the Fe(III) complex with 250 carboxylic groups of FA degraded 4-fold in both fen and stream water, whereas phenolic complex of 251 Fe(III) remained stable (Table S2). The proportion of Fe(II) complex with carboxylates of FA 252 increased whereas Fe(II)-weak electrostatic complex completely disappeared. This is consistent with 253 highly reactive behavior of dissolved Fe(II) in biodegradation experiments.

The second $<0.22 \mu \mathrm{m}$ filtration step in the laboratory of the control water samples showed 255 that the 6 months storage in the fridge did not affect stream water chemical composition but it 256 induced a decrease of Fe concentration in the fen water from $4310 \mu \mathrm{g} / \mathrm{L}$ to $2470 \mu \mathrm{g} / \mathrm{L}$, accompanied 257 by a change in $\delta^{57} \mathrm{Fe}$ from $0.25 \pm 0.06 \%$ to $1.06 \pm 0.04 \%$. A strong $\delta^{57} \mathrm{Fe}$ increase from $1.59 \pm 0.05 \%$ o to $2582.87 \pm 0.07 \%$ also resulted from the storage for the stream water (Table 1 and S1). This change could 259 be linked to some $\mathrm{Fe}(\mathrm{OH})_{3}$ precipitation due to either aggregation of $\mathrm{Fe}(\mathrm{III})$-rich organic colloids or 260 Fe(II) oxidation. To preserve at least the Fe isotopic composition of DOC-rich waters over several 261 months, immediate freezing after filtration in the field on the sampling site is preferable ${ }^{50}$, but this is 262 not always possible for logistical reasons.

Although the fractionation of Fe between bacterial cells and organo-ferric colloids has not been 264 studied previously, the adsorption of metal cations such as $\mathrm{Zn}^{2+}$ at the microorganism cell surface is 265 known to favor the heavier isotopes ${ }^{51}$ and both $\mathrm{Fe}^{2+}$ and $\mathrm{Fe}^{3+}$ ions follow this rule ${ }^{30,31}$. The heavier Fe 266 isotopes are preferentially adsorbed onto solid surfaces during equilibrium isotope fractionation 267 processes $^{36}$. Experiments that lasted 11 days with anaerobic phototrophic Fe-oxidizing, aerobic 268 neutrophilic Fe-oxidizing, and heterotrophic Fe-reducing bacteria demonstrated that metabolically269 produced hydrous ferric oxide (HFO) exhibited heavier isotopic composition than the initial Fe(II), 270 with a fractionation factor $\left(\Delta^{57} \mathrm{Fe}\right)$ of $+2.2 \pm 0.3 \%{ }^{52}$. Further, depending on the phytoplankton species 271 and the composition of the culture medium, the cell surface was found to be enriched in heavier 
272 isotopes by $+2.4 \pm 0.6 \%$ to $+2.9 \pm 0.1 \%$ for $\mathrm{Fe}^{2+}$ containing solution and by $+0.4 \pm 0.2$ to $+1.0 \pm 0.2 \%$ o

273 for $\mathrm{Fe}^{3+}$ solution ${ }^{30}$. More recent measurements of $\mathrm{Fe}$ isotope fractionation during Fe adsorption onto 274 phytoplankton cells quantitatively confirmed these data ${ }^{31}$. The value $\Delta^{57} \mathrm{Fe}_{\text {cell-solution }}$ of $+0.5 \pm 0.1 \%$ for 275 the river water inferred from the present study suggests essentially $\mathrm{Fe}^{3+}$ ion adsorption onto $P$. 276 aurefaciens cell surfaces, presumably forming Fe(III)-phosphoryl complexes ${ }^{44}$. Note however that 277 the competition between surface organic moieties and aqueous organic complexes for heavy $\mathrm{Fe}$ 278 isotopes can decrease the magnitude of isotopic offset in humic waters compared to experimental 279 solutions with low DOC. At present, the isotopic offset for adsorption of organo-ferric colloids onto 280 organic surfaces is not known and this should be the subject of future research.

The interaction of stream water with heterotrophic bacterium produced first, a drop in $\delta^{57} \mathrm{Fe}$ 282 of ca $0.4 \%$ in solution due to adsorption of heavier isotopes on the cell surface, and then a gradual 283 increase in aqueous $\delta^{57} \mathrm{Fe}$ from $+2.5 \pm 0.1 \%$ o to $+3.2 \pm 0.1 \%$ o between 1 and $24 \mathrm{~h}$ (Fig. 3 A) yielding $284 \Delta \Delta^{57} \mathrm{Fe}_{\text {cell-solution }}$ of $-0.7 \%$. This implies removal of lighter $\mathrm{Fe}$ isotopes due to their preferential 285 intracellular uptake. After an initial drop in the stream water $\delta^{57} \mathrm{Fe}$, the long-term removal of lighter 286 Fe isotopes by live bacteria produced ca $0.7 \%$ increase in $\delta^{57} \mathrm{Fe}$ over the first $20 \mathrm{~h}$ of reaction that 287 remained constant to $50 \mathrm{~h}$ (Fig. 3A). This strongly supports biological mechanism of lighter Fe 288 isotopes uptake inside cells rather than metabolically-induced $\mathrm{Fe}(\mathrm{OH})_{3}$ precipitation. In the latter 289 case, the solid phase would be enriched in heavy isotope $\left(\Delta^{57} \mathrm{Fe}_{\mathrm{FeOOH}-\mathrm{Fe}(\mathrm{aq})}=+1.5 \text { to }+4-5 \% \text { o }\right)^{32,53,54}$ as 290 also supported by natural observations ${ }^{9,53}$. The present result is at variance with previous $\mathrm{Fe}$ 291 assimilation by magnetotactic bacteria ${ }^{33}$ or phytoplankton $^{42}$ that inferred a heavier Fe isotope uptake 292 inside the cells due to a combined Fe oxidation. However, the Fe(III)-DOM complexes in solution 293 retain heavy isotope as it is known for $\mathrm{Fe}^{3+}\left(\mathrm{H}_{2} \mathrm{O}\right)_{6}-\mathrm{Fe}(\mathrm{III})$ chelate (DFO-B): the organic complexes 294 are enriched in heavy isotopes with an isotopic offset of $+0.90 \pm 0.23 \% 55$, and overall, there is a 295 strong positive correlation between Fe fractionation factors and the Fe-binding affinity of the 296 ligands ${ }^{56}$. According to vMinteq calculation, the majority of Fe in our experimental solutions was 297 bound to phenolic complexes with fulvic acids (Fig. S1, Table S2). Therefore, we suggest that strong 
298 complexation of isotopically heavy Fe(III) with DOM prevents the intracellular uptake of heavier Fe 299 isotopes.

300 In the fen water, we observed a similar $\delta^{57} \mathrm{Fe}$ evolution during biodegradation experiments, 301 though with smaller variations. The isotopic composition of dissolved Fe did not appreciably change 302 during $P$. aureofaciens short-term interaction with fen water: we observed only weak adsorption of 303 heavy isotope $\left(<0.1 \%\right.$ ) and a weak assimilation of light isotopes $\Delta^{57} \mathrm{Fe}_{\text {cell-solution }} \leq 0.1 \%$ over first 40

$304 \mathrm{~h}$ (Fig. 3 B). Relative to the sterile control, a decrease in $\delta^{57} \mathrm{Fe}$ at the beginning of experiment 305 signified preferential adsorption of heavy isotopes with $\Delta^{57} \mathrm{Fe}_{\text {cell-solution }}=+0.2 \pm 0.1 \%$. Over $100 \mathrm{~h}$ of 306 reaction, light $\mathrm{Fe}$ isotopes were taken up by the cells as the $\delta^{57} \mathrm{Fe}$ of solution increased from $307+0.86 \pm 0.1 \%$ to $+1.05 \pm 0.05 \%$.

308 Overall, the effect of bio-transformation of $\mathrm{Fe}$ isotopic signature were much stronger in the 309 stream water compared to the fen water, which may be due to different concentration of Fe in these 310 two samples $(200$ and $4300 \mu \mathrm{g} / \mathrm{L})$ at otherwise similar bacterial concentration $\left(1 \mathrm{~g}_{\mathrm{wet}} / \mathrm{L}\right)$. As a result, 311 there was an order of magnitude higher ligand : metal ratio ((cell surface sites) : Fe fraction) in the 312 stream compared to the fen water.

3.2. Iron concentrations and isotopic signatures evolution during photodegradation of organo-ferric colloids: Removal of heavier isotopes due to Fe(III) hydroxide formation and appearance of

DOC concentration in $<0.22 \mu \mathrm{m}$ fraction of stream and fen water decreased by 30 and $50 \%$, respectively, over 200 to $250 \mathrm{~h}$ of photodegradation experiment (Table 1). There was a good correlation between ultraviolet absorbency $\left(\mathrm{UV}_{254 \mathrm{~nm}}\right)$ and Fe concentration in the fen water $\left(\mathrm{R}^{2}=\right.$ isotopically light Fe(II) in the LMW fraction

There was no $\mathrm{pH}$ variation in the course of photodegradation experiments: within the uncertainty of duplicates $(<0.1-0.2 \mathrm{pH}$ unit $)$, the $\mathrm{pH}$ in the dark control and the light experiment was identical and equal to $7.0 \pm 0.2$ and $5.3 \pm 0.1$ in the stream and fen water, respectively (Table 1 and $\mathrm{S} 1$ ). The $0.928)$ which was absent in the stream water in the course of experiment $\left(\mathrm{R}^{2}=0.19\right)$. 
In the stream water, $\mathrm{Fe}$ concentration remained generally constant within the uncertainties

over $250 \mathrm{~h}$ of exposure to sunlight, relative to the dark control, and no formation of flocculent material was noted (Fig. 4 A). There was 50 to $80 \%$ removal of Fe(II), between 110 and $250 \mathrm{~h}$ of exposure, which occurred for both $<0.22 \mu \mathrm{m}$ and $<10 \mathrm{kDa}$ fractions (from 50 to $15 \mu \mathrm{g} / \mathrm{L}$ and from 20 $\mu \mathrm{g} / \mathrm{L}$ to $<$ limit of quantification, respectively, Fig. 4 B).

The removal of Fe during fen water exposure to sunlight was strong in the $<0.22 \mu \mathrm{m}$ fraction $(\sim-75 \%$ of initial concentration) and did not occur in the $<10 \mathrm{kDa}$ fraction $(\leq 7 \%$ of the initial concentration, Fig. $4 \mathrm{D}$ and Table 1). A notable increase in total Fe concentration (ca. 210\%) in the $\mathrm{LMW}_{<1 \mathrm{kDa}}$ fraction was observed over $200 \mathrm{~h}$ of exposure (Fig. 4 D). The divalent Fe concentration decreased by $50 \%$ in the $<0.22 \mu \mathrm{m}$ fraction but strongly increased $(\sim 500 \%)$ in the $<1 \mathrm{kDa}$ fraction (Fig. 4 E and Table 1). Over $196 \mathrm{~h}$ of irradiation, the Fe(II) proportion increased from 20 to $50 \%$ in the $<0.22 \mu \mathrm{m}$ fraction and from 35 to $55 \%$ in the $<1 \mathrm{kDa}$ fraction. The $<10 \mathrm{kDa}$ fraction did not demonstrate any difference in Fe(II) concentration between the sunlight-irradiated samples and the dark control.

During sunlight exposure, the $<0.22 \mu \mathrm{m}$ fraction of the fen water became depleted in $\mathrm{Fe}$ as the molar ratio of $\mathrm{C}_{\mathrm{org}}: \mathrm{Fe}$ increased from 50 to 100 , as can be calculated from evolution of concentrations listed in Table 1. This trend mainly stems from more efficient Fe removal compared to DOC. The change of this ratio in the stream water was within the experimental uncertainty. The $\mathrm{C}_{\text {org }}$ :Fe ratio in the fen water colloids $(1 \mathrm{kDa}-0.22 \mu \mathrm{m})$ did not change in the course of photodegradation, from 31 at the beginning of experiment to 32 after $193 \mathrm{~h}$ of sunlight exposure. In the $\mathrm{LMW}_{<1 \mathrm{kDa}}$ fraction of fen water, the $\mathrm{C}_{\mathrm{org}}:$ Fe ratio decreased from 247 to 126.

All size fractions of the initial stream solution and the $\mathrm{LMW}_{<1 \mathrm{kDa}}$ fraction of the fen water were undersaturated with respect to Fe-bearing minerals. The initial $<0.22 \mu \mathrm{m}$ fen water was supersaturated with respect to goethite, lepidocrocite and magnetite (Saturation Indexes $=1.3,0.62$, and 3.6, respectively). The speciation calculation using vMinteq also demonstrated that Fe(III) is fully complexed with DOM (Fig. S2). Therefore, the removal of $\mathrm{Fe}$ in the form of particulate $\mathrm{Fe}$ 
350 hydroxide could be only due to liberation of part of Fe from organic complexes after photolytic 351 degradation of colloidal DOM that stabilized Fe (III) polymers in solutions. Calculated Fe(II) and $352 \mathrm{Fe}(\mathrm{III})$ speciation in the fen water before and after photodegradation experiment demonstrated an 353 appearance of $\sim 2 \%$ of inorganic Fe(II) and approx. 2-fold increase of Fe(II) bound to DOM, in both $354<0.22 \mu \mathrm{m}$ and $<1 \mathrm{kDa}$ size fraction (Fig. S2). In the stream water, there was a 3-fold decrease of $355 \mathrm{Fe}(\mathrm{II})$ bound to DOM. Specifically, the Fe(III) complex with carboxylic groups of FA decreased and 356 increased 3-fold in fen and stream waters, respectively (Table S3). Phenolic complexes of Fe(III) 357 which accounted for $>93 \ldots 99 \%$ of all Fe, remained constant in the course of experiment. In the fen 358 water, the proportion of Fe(II)-weak electrostatic complex strongly decreased (by a factor of 4.5 and 3591.5 in $<0.22 \mu \mathrm{m}$ and $<1 \mathrm{kDa}$ fractions, respectively) whereas Fe(II) complex with FA carboxylates 360 increased in $<0.22 \mu \mathrm{m}$ fraction and stayed constant in $<1 \mathrm{kDa}$ fraction (Table S3). According to 361 vMinteq predictions, $4.5 \times 10^{-5} \mathrm{M}$ of ferrihydrite should could have precipitated from the fen water 362 over $200 \mathrm{~h}$ of solar irradiation. This is equivalent to $\sim 2250 \mu \mathrm{g} / \mathrm{L}$ of dissolved $\mathrm{Fe}$ concentration 363 decrease, which is comparable to the range encountered in the experiment (ca. $3400 \mu \mathrm{g} / \mathrm{L}$, see Fig. 4 364 D and Table 1).

The isotopic signature of stream water samples remained constant in the $<0.22 \mu \mathrm{m}$ fraction 366 of dark control and sun-light irradiated quartz reactors (Fig. 5A). The $\delta^{57} \mathrm{Fe}$ value of the $<10 \mathrm{kDa}$ 367 fraction decreased from $+2.93 \pm 0.05 \%$ to $+1.92 \pm 0.1 \%$ after first $110 \mathrm{~h}$ of exposure and then 368 remained constant. Note that the initial $<10 \mathrm{kDa}$ fraction of stream water was ca. $1.5 \%$ isotopically 369 heavier than the $<0.22 \mu \mathrm{m}$ fraction, in agreement with previous measurement of $\mathrm{Fe}$ isotopic 370 composition in colloids of Northern Karelian streams ${ }^{37}$.

371 The isotopic ratio in the dark control of fen water remained stable at $\delta^{57} \mathrm{Fe}=0.2 \pm 0.3 \%$, 372 except in the $\mathrm{LMW}_{<1 \mathrm{kDa}}$ fraction, where a $+0.6 \%$ increase was observed, related to the Fe and DOC 373 loss (Table S1). Similar effect was reported in the organic-rich Negro River where it was attributed 374 to the loss of isotopically light aggregates of $\mathrm{Fe}(\mathrm{III})$ with $\mathrm{OM}^{50}$. In contrast to dark controls, sunlight 375 irradiation of the fen water strongly impacted $\delta^{57} \mathrm{Fe}$ in all 3 fractions, $<0.22 \mu \mathrm{m},<10 \mathrm{kDa}$ and $<1$ 
$376 \mathrm{kDa}$ (Fig. 5 B). Over first $100 \mathrm{~h}$ of reaction, there was sizeable, from 1 to $2 \%$, decrease of $\delta^{57} \mathrm{Fe}$ in 377 the $<0.22 \mu \mathrm{m}$ and the $<1-10 \mathrm{kDa}$ fraction, respectively. Over the next $100 \mathrm{~h}$, the $\delta^{57} \mathrm{Fe}$ further 378 decreased by $1.5 \%$ in the $<0.22 \mu \mathrm{m}$ fraction and stabilized at $\delta^{57} \mathrm{Fe}=-2.2 \pm 0.2 \%$ in the $<1$ and $<10$ $379 \mathrm{kDa}$ fractions.

380 Sunlight exposure of stream water did not produce any sizable change of Fe concentration and 381 isotopic signature in the $<0.22 \mu \mathrm{m}$ fraction (Fig. 4A and 5A), in general agreement with stability of 382 boreal high latitude metal concentration in riverwaters with respect to sunlight irradiation ${ }^{28,57}$. After $383100 \mathrm{~h}$ of sunlight irradiation, the $<10 \mathrm{kDa}$ fraction of stream water became $1.5 \%$ lighter compared 384 to the initial value or the dark control (Fig. 5A), although the Fe concentration in this fraction 385 decreased only between 100 and $250 \mathrm{~h}$ of exposure (Fig. 4 A). A plausible explanation for this 386 isotopic pattern invokes the presence of strong low molecular weight $(<10 \mathrm{kDa}) \mathrm{Fe}(\mathrm{III})$-organic 387 ligand (chelate) complexes which are enriched in heavy isotopes ${ }^{55}$ and which are capable to stabilize 388 dissolved Fe. For example, aquatic prokaryotes produce the LMW $(0.3-1 \mathrm{kDa}) \mathrm{Fe}(\mathrm{III})$ 389 siderophores $^{58}$. These light sensitive, presumably aromatic Fe complexes represent a small iron 390 fraction of overall $\mathrm{Fe}_{<10} \mathrm{kDa}$ pool, but our results indicate that it exhibits a very high $\delta^{57} \mathrm{Fe}$ value. The 391 isotopic signature of $\mathrm{LMW}_{<1-10 \mathrm{kDa}}$ Fe poor, C-rich fraction of Karelian waters reaches $+4.2 \%{ }^{37}$. We 392 hypothesize that these isotopically heavy Fe-organic complexes have low residence time in the river 393 channel and are produced due to periphyton or plankton metabolic activity.

394 The $\mathrm{Fe}$ in the fen water was strongly sensitive to sunlight irradiation as $>70 \% \mathrm{Fe}$ was removed 395 from the $<0.22 \mu \mathrm{m}$ fraction and all filtrates and ultrafiltrates became strongly impoverished in heavy 396 isotopes (Fig. 4 D, 5 B). The removal of Fe followed that of $\mathrm{SUVA}_{254}$ decrease ${ }^{28}$, suggesting that the 397 majority of $\mathrm{Fe}$ that is removed from the fen water was bound to aromatic (colored) organic carbon. 398 This is also confirmed by the dominance of Fe(III)-phenolic groups of FA in Fe speciation (Table 399 S3). It is possible that the photolysis of Fe-DOM complexes liberates ionic Fe which could be 400 removed from solution in the form of isotopically heavy Fe hydroxides. The removal of heavy 401 isotopes by sunlight oxidation of organo-ferric colloids observed in this study $(+2.3 \pm 0.1 \%$ ) is 
generally consistent with known fractionation of $\mathrm{Fe}$ between $\mathrm{Fe}(\mathrm{III})$ hydroxide and $\mathrm{Fe}(\mathrm{II})$ solution:

$403\left(\Delta^{57} \mathrm{Fe}_{\mathrm{FeOOH}-\mathrm{Fe}(\mathrm{aq})}=+2.3 \pm 0.3 \%\right.$, ref. 52-54).

In contrast to what was hypothesized in our earlier work on these waters ${ }^{37}$, no enrichment in heavy isotopes of LMW fraction was observed during photolysis of humic waters. Here we suggest that $\mathrm{Fe}$ (II) generated in the $<1 \mathrm{kDa}$ fraction is enriched in light isotopes compared with initial Fe(III) in colloids, thus producing overall negative $\delta^{57} \mathrm{Fe}$ value in $\mathrm{LMW}_{<1 \mathrm{kDa}}$ after irradiation. Assuming an equilibrium fractionation factor between $\mathrm{Fe}(\mathrm{II})$ and $\mathrm{Fe}(\mathrm{III})$ of $-4.3 \%{ }^{59}$ and considering the starting water $\delta^{57} \mathrm{Fe}$ close to $0 \%$ (Fig. 5B), the $55 \%$ of $\mathrm{Fe}(\mathrm{II})$ in $<1 \mathrm{kDa}$ fraction $($ Fig. 4 F) provides $0.55 \times(-$ $4.3 \%$ o $=-2.4 \%$ of $\delta^{57} \mathrm{Fe}$, in full agreement with values shown in Fig. 5 B. This $<0.22 \mu \mathrm{m}$ fraction comprises two Fe pools: (1) Fe remaining after $\mathrm{Fe}^{2+}(\mathrm{aq}) \rightarrow \mathrm{Fe}(\mathrm{OH})_{3}$ and after $\mathrm{Fe}^{3+}$ (colloidal) $\rightarrow$ $412 \mathrm{Fe}(\mathrm{OH})_{3}$ precipitation, and (2) isotopically light $\mathrm{Fe}^{2+}$ produced in the LMW fraction. It is important 413 to note that the photolysis of organo-ferric colloids which represents $80 \%$ of Fe in $<0.22 \mu$ m fraction, 414 removes $\mathrm{Fe}(\mathrm{III})$ in the form of $\mathrm{Fe}(\mathrm{OH})_{3}$ hydroxides corresponding to $\Delta^{57} \mathrm{Fe} \mathrm{Fe}_{\text {(III)hydroxide-Fe(aq) of }}$ $4152.4 \pm 0.1 \%$, Fig 5B. The observed enrichment of solid phase in heavier isotopes is therefore much 416 lower than $\mathrm{Fe}^{2+}(\mathrm{aq}) \rightarrow \mathrm{Fe}(\mathrm{OH})_{3}$ reaction $\left(\Delta^{57} \mathrm{Fe}_{\mathrm{Ferrihydrite}-\mathrm{Fe}(\mathrm{II})}=4.7 \%{ }^{39}\right)$ and opposite in sign to $417 \mathrm{Fe}^{3+}(\mathrm{aq}) \rightarrow \mathrm{Fe}(\mathrm{OH})_{3}$ reaction $\left(\Delta^{57} \mathrm{Fe}_{\mathrm{Fe}(\mathrm{III}) \text { hydroxide-Fe(aq) }}=-0.9 \%^{60}\right)$. Lower value of isotopic 418 enrichment compared to the equilibrium fractionation factor between Fe(II)aq and pure ferrihydrite ${ }^{39}$ 419 may be due to Fe(II) sorption onto hydrous Fe(III)-oxides and subsequent atom (isotope) exchange 420 between $\mathrm{Fe}(\mathrm{II})$ and hydrous $\mathrm{Fe}(\mathrm{III})$-oxides. These processes are known to be responsible for 421 substantial Fe isotope fractionation in a number of organic-free systems ${ }^{36,61-64}$. However, in humic 422 waters, both remaining $\mathrm{Fe}(\mathrm{II})_{\mathrm{aq}}$ ions and $>\mathrm{FeOOH}$ surface sites of newly precipitated $\mathrm{Fe}(\mathrm{III})$ 423 hydroxides are likely to be bound to carboxylic and phenolic groups of fulvic acids. Organic matter 424 associated with Fe(III) hydroxide and surface organic - Fe complexes may modify the magnitude of $425 \mathrm{Fe}(\mathrm{II})-\mathrm{Fe}(\mathrm{III})$ hydroxide isotope exchange ${ }^{34}$. Thus, Chanda et $\mathrm{al}^{65}$ argued that the presence of organic $426 \mathrm{C}$ causes distortion of the $\mathrm{Fe}$ octahedral structure and decreases by ca. $1.2 \%$ \% $\left({ }^{57} \mathrm{Fe} /{ }^{54} \mathrm{Fe}\right)$ the 427 fractionation factor between Fe(II) and NOM-ferrihydrite. Similar mechanisms may operate in case 
428 of isotopic exchange between $\mathrm{Fe}(\mathrm{II})$ and organo-ferric aggregates produced by photolysis of $\mathrm{Fe}(\mathrm{III})$ 429 rich colloids.

$430 \quad$ We observed notable differences in the degree of $\mathrm{Fe}$ concentrations and $\mathrm{Fe}$ isotopic 431 composition during photolysis of the fen and the stream water. These differences may stem from the 432 combination of two main factors controlling the degree of DOM and Fe photo-reactivity in natural 433 waters: the fen water is a 1.5 unit of $\mathrm{pH}$ lower than the stream and has a factor of 30 higher in $\mathrm{Fe}$ 434 concentration. The water acidity is known to exert a strong positive effect on the photolysis of $435 \mathrm{DOM}^{65,66}$ and the DOM photobleaching is enhanced by elevated Fe concentration via the photo436 Fenton effect below $\mathrm{pH} 6^{67}$. Overall, in natural settings, one may expect large variation of $\mathrm{Fe}$ and 437 DOM photo-liability depending on the environmental context. Thus, slightly alkaline $(\mathrm{pH}=8)$ 438 surface water from a temperate peatland in China exhibited quite higher photo-stability of $\mathrm{Fe}^{68}$, 439 whereas acidic DOC-rich waters from a subtropical swamp under UV irradiation demonstrated 10 440 times more efficient removal of Fe relative to $\mathrm{DOC}^{69}$. As such, depending on the lithological context 441 of peatlands (i.e., acidic (felsic) or carbonate (sedimentary) rocks), the degree of Fe chemical and 442 isotopic composition change under sunlight may be dramatically different. waters Fe isotope budget

446 We hypothesize several processes responsible for chemical removal and isotopic redistribution of 447 Fe among different colloidal pools in DOM- and Fe-rich stream and fen water, shown schematically 448 in Fig. 6. High molecular size $(10 \mathrm{kDa}-0.45 \mu \mathrm{m})$ organo-ferric colloids representing the majority of 449 dissolved $(<0.22 \mu \mathrm{m}) \mathrm{Fe}^{17,37}$ are stabilized by organic ligands originating from topsoil and bog peat 450 leaching. In addition, a small fraction of $\mathrm{Fe}(\mathrm{III})$ could be linked to highly specific, $\mathrm{LMW}_{<1-10 \mathrm{kDa}}$ 451 ligands having a short residence time in the river channel; these complexes could be produced via in452 stream plankton and periphyton activity. In the fen water, a sizeable fraction of $\mathrm{Fe}$ is in the form of $453 \mathrm{Fe}(\mathrm{II})$ inorganic and organic complexes ${ }^{70}$. In the river water, the HMW colloids are subjected to 
454 biologically-controlled transformations via $i$ ) adsorption onto surfaces of aquatic bacteria, favoring 455 heavier isotopes to the cells, with an overall $\Delta^{57} \mathrm{Fe}_{\text {cell ads-solution }}=+0.4 \pm 0.1 \%$, and $i$ ) assimilation by 456 live bacteria, favoring lighter $\mathrm{Fe}$ isotopes to the cells with $\Delta^{57} \mathrm{Fe}_{\text {cell }}$ incorp-solution $=-0.7 \pm 0.1 \%$. On a 457 short-term scale (hours), the humic waters, once placed in contact with bacteria, are therefore 458 becoming enriched in lighter Fe isotopes, followed, on a long-term scale (days), by enrichment in 459 heavier Fe isotopes. Considering available data on preferential heavy isotope adsorption onto 460 phytoplanktonic and peryphytic cyanobacteria inhabiting natural waters (from +0.4 to $+2.9 \%$, ref. 46130 ), and neglecting Rayleigh distillation processes given that we are dealing with open systems 462 (hydrological continuum, ref. 17), the overall magnitude of diurnal variation of dissolved $(<0.45$ $463 \mu \mathrm{m}) \delta^{57} \mathrm{Fe}$ in small streams and stagnant surface waters in the presence of common soil bacteria may 464 range from $+2.7 \%$ to $+0.7 \%$. This greatly exceeds the range of $\mathrm{Fe}$ isotopic excursions in various 465 sediments and in all possible bedrocks ${ }^{71}$.

466 Further, photolysis of DOM and Fe-DOM complexes in surface waters, which operates at the 467 time scale comparable to water and solute residence time in these waters (1-10 days), is capable to 468 dramatically enrich in lighter Fe isotopes (by 1.5 to $2.5 \%$ ) of both dissolved $(<0.22 \mu \mathrm{m})$ and $\mathrm{LMW}_{<}$ $469 \quad 1-10 \mathrm{kDa}$ water fraction. We suggest that the two major processes of organo-ferric colloid 470 transformation under sunlight in natural waters include: $(i)$ degradation of the organic part of colloids $471(1 \mathrm{kDa}-0.22 \mu \mathrm{m})$ and production of low molecular weight $(<1 \mathrm{kDa})$ organic ligands including 472 carboxylic and aromatic chelates capable of strong binding of Fe ions; (ii) aggregation of HMW 473 organo-ferric colloids and precipitation of Fe-rich oxy(hydroxide) after the solar radiation-induced 474 removal of stabilizing organic matter.

475 The enigmatic enrichment of the LMW fraction $(<1-10 \mathrm{kDa})$ of the stream water in heavy 476 isotopes $^{37}$ is therefore most likely linked to strong, presumably aromatic, isotopically heavy Fe(III)477 organic complexes. These compounds have low residence time and are produced in the river channel 478 due to periphyton or plankton metabolic activity. In addition, sunlight irradiation of subarctic humic 479 waters may produce 10 -fold increase in aliphatic and aromatic carbonic acids ${ }^{72}$ capable to bind both 

waters can produce from -2 to $+3 \% \delta^{57} \mathrm{Fe}$ variation on time scales of a few days. Because this time is generally shorter than the water residence time in surface waters, considering of Fe isotopic signature of rivers and streams as a conservative value inherited from soils and using it for tracing the sources and weathering regime on watersheds are not warranted at short time- and length-scales.

Therefore, naturally-induced variations in biological activity (switching from heterogenic bacteria uptake to adsorption onto aquatic phototrophs) and sunlight illumination can modify the overall Fe isotopic signatures of surface waters by several permil. Moreover, when considering the processes responsible for Fe chemical and isotopic transformation in organic-rich streams, one has to assess both dissolved $(<0.45$ or $<0.22 \mu \mathrm{m})$ and $\mathrm{LMW}_{<1-10 \mathrm{kDa}}$ fractions of metal, since their isotopic signatures and photo-susceptibility may be dramatically (by 1 to 3\%) different.

We acknowledge support from a RFBR research projects № 17-05-00342_a, and 18-05-00162, and the CNRS (PRC) No 1070 project. We thank P. Télouk in Lyon and J. Chmeleff in Toulouse for maintaining the MC-ICP-MS instruments in good working order, and M. Henri for maintaining the

\section{Acknowledgements} clean room in Toulouse.

\section{References}

(1) Beard, B.L.; Johnson, C.M.; Von Damm, K.L.; Poulson, R.L. Iron isotope constraints on Fe cycling and mass balance in oxygenated Earth oceans. Geology 2003, 31, 629-632.

(2) Labatut, M.; Lacan, F.; Pradoux, C.; Chmeleff, J.; Radic, A.; Murray, J.W.; Poitrasson, F.; Johansen, A.M.; Thil, F. Iron sources and dissolved-particulate interactions in the seawater of the Western Equatorial Pacific, iron isotope perspectives. Global Biogeochem. Cycles 2014, 28, $1044-$ 1065.

(3) Ingri, J.; Malinovsky, D.; Rodushkin, I.; Baxter, D.C.; Widerlund, A.; Andersson, P.; Gustafsson, O.; Forsling, W.; Ohlander, B. Iron isotope fractionation in river colloidal matter. Earth Planet. Sci. Lett. 2006, 245 (3-4), 792-798.

(4) Ingri, J.; Conrad, S.; Lidman, F.; Nordblad, F.; Engstrom, E.; Rodushkin, I.; Porcelli, D. Iron isotope pathways in the boreal landscape: Role of the riparian zone. Geochim. Cosmochim. Acta 2018, 239, 49-60.

(5) Escoube, R.; Rouxel, O.; Pokrovsky, O.S.; Schroth, A.; Holmes, R.M.; Donard, O.F.X. Iron isotope systematics in Arctic rivers. Comptes Rendus Geoscience 2015, 347 (7-8), 377-385; DOI 10.1016/j.crte.2015.04.005.

(6) Conrad, S.; Ingri, J.; Gelting, J.; Nordblad, F.; Engström, E.; Rodushkin, I.; Andersson, P.S.; Porcelli, D.; Gustafsson, Ö.; Semiletov, I.; Öhlander, B. Distribution of Fe isotopes in particles and 
colloids in the salinity gradient along the Lena River plume, Laptev Sea. Biogeosciences, 2019, 16,

(7) Chen, J.B.; Busigny, V.; Gaillardet, J.; Louvat, P.; Wang, Y.N. Iron isotopes in the Seine River (France): Natural versus anthropogenic sources. Geochim. Cosmochim. Acta 2014, 128, 128-143.

(8) Poitrasson, F.; Vieira, L.C.; Seyler, P.; dos Santos Pinheiro, G.M.; Mulholland, D.S.; Bonnet, M.P.; Martinez, J.M.; Lima, B.A.; Allard, T.; Boaventura, G.R.; Chmeleff, J.; Dantas, E.; Guyot, J.L.; Mancini, L.; Pimentel, M.M.; Santos, R.V.; Sondag, F.; Vauchel, P. Iron isotope composition of the bulk waters and sediments from the Amazon River Basin. Chem. Geol. 2014, 377, 1-11.

(9) Song, L.; Liu, C.-Q.; Wang, Z.-L.; Zhu X.; Teng, Y.; Liang, L.; Tang, S.; Li, J. Iron isotope fractionation during biogeochemical cycle: information from suspended particulate matter (SPM) in Aha Lake and its tributaries, Guizhou, China. Chem. Geol. 2011, 280 (1-2), 170-179.

(10) Busigny, V.; Planavsky, N.J.; Jezequel, D.; Crowe, S.; Louvat, P.; Moureau, J.; Viollier, E.; Lyons, T.W. Iron isotopes in an Archean ocean analogue. Geochim. Cosmochim. Acta 2014, 133, 443-462.

(11) Serikova, S.; Pokrovsky, O.S.; Ala-aho, P.; Kazantsev, V.; Kirpotin, S.; Kopysov, S.; Krickov, I.; Laudon, H.; Manasypov, R.M.; Shirokova, L.S.; Soulsby, C.; Tetzlaff, D.; Karlsson, J. High riverine $\mathrm{CO}_{2}$ emissions at the permafrost boundary of Western Siberia. Nature Geoscience 2018, 11, 825-829.

(12) Serikova, S., Pokrovsky, O.S., Laudon, H., Krickov, I.V., Lim, A.G., Manasypov, R.M., Karlsson, J. High carbon emissions from thermokarst lakes of Western Siberia. Nature Comm., 2019, 10, Art No 1552. https://doi.org/10.1038/s41467-019-09592-1.

(13) Kritzberg, E.S.; Villanueva, A.B.; Jung, M.; Reader, H.E. Importance of boreal rivers in providing iron to marine waters. PLOS ONE 2014, 9, e107500, DOI 10.1371/journal.pone.0107500.

(14) Hirst, C.; Kutscher, L; Murphy, M; Shaw, S.; Burke, I.T.; Kaulich, B.; Maximov, T.; Pokrovsky, O.S.; Mörth, C.-M; Andersson, P.S.; Porcelli, D. Characterization and stability of Febearing particles in the Lena River catchment, NE Russia. Geochim. Cosmochim. Acta 2017, 213, $553-573$.

(15) Hassellov, M.; Von Der Kammer, F. Iron oxides as geochemical nanovectors for metal transport in soil-river systems. Elements 2008, 4 (6), 401-406.

(16) Vonk, J.E.; Tank, S.E.; Bowden, W.B.; Laurion, I.; Vincent, W.F.; Alekseychik, P.; Amyot, M.; Billet, M.F.; Canário, J.; Cory, R.M.; Deshpande, B.N.; Helbig, M.; Jammet, M.; Karlsson, J.; Larouche, J.; MacMillan, G.; Rautio, M.; Walter Anthony, K.M.; Wickland, K.P. Reviews and Syntheses: Effects of permafrost thaw on Arctic aquatic ecosystems. Biogeosciences 2015, 12, 71297167.

(17) Ilina, S.M.; Lapitsky, S.A.; Alekhin, Y.V.; Viers, J.; Benedetti, M.; Pokrovsky, O.S. Speciation, size fractionation and transport of trace element in the continuum soil water - mire - lake - river - large oligotrophic lake of a subarctic watershed. Aquat. Geochem. 2016, 22 (1), 65-95.

(18) Shirokova, L.S.; Bredoire, R.; Rolls, J.-L.; Pokrovsky, O.S. Moss and peat leachate degradability by heterotrophic bacteria: fate of organic carbon and trace metals. Geomicrobiology $J$. 2017, 34 (8), 641-655.

(19) Kopacek, J.; Klementova, S.; Norton, S.A. Photochemical production of ionic and particulate aluminum and iron in lakes. Environ. Sci. Technol. 2005, 39, 3656-3662.

(20) Shiller, A.M.; Duan, S.; van Erp, P.; Bianchi, T.S. Photo-oxidation of dissolved organic matter in river water and its effect on trace element speciation. Limnol. Oceanography 2006, 51(4), $1716-1728$

(21) Mann, P.J.; Sobczak, W.V.; LaRue, M.M.; Bulygina, E.; Davydova, A.; Vonk, J.E.; Schade, J.; Davydov, S.; Zimov, N.; Holmes, R.M.; Spencer, R.G.M. Evidence for key enzymatic controls on metabolism of Arctic river organic matter. Global Change Biol. 2014, 20 (4), 1089-1100.

(22) Vähätalo, A.V.; Salonen, K.; Münster, U.; Järvinen, M.; Wetzel, R.G. Photochemical transformation of allochthonous organic matter provides bioavailable nutrients in a humic lake. Acta Hydrobiol. 2003, 156, 287-314. 
(23) Kelton, N.; Molot, L.A.; Dillon, P.J. Effect of ultraviolet and visible radiation on iron lability in boreal and artificial waters. Aquat. Sci. 2007, 69, 86-95.

(24) Garg, S.; Ito, H.; Rose, A.L.; Waite, T.D. Mechanism and kinetics of dark iron redox transformations in acidic natural organic matter solutions. Environ. Sci. Technol. 2013, 47, 1861-1867.

(25) Blazevic, A.; Orlowska, E.; Kandioller, W.; Jirsa, F.; Keppler, B.K.; Tafili-Krueziu, M.; Linert, W.; Krachler, R.F.; Krachler, R.; Rompel, A. Photoreduction of terrigenous Fe-humic substances leads to bioavailable iron in oceans. Angew. Chem. Int. Ed. 2016, 55, 6417-6422.

(26) Oleinikova, O.V.; Shirokova, L.S.; Drozdova, O.Yu.; Lapitskiy, S.A.; Pokrovsky, O.S. Low biodegradability of dissolved organic matter and trace metals from subarctic waters. Sci. Total Env. 2018, 618, 174-187.

(27) Oleinikova, O.V.;Shirokova, L.S.; Gérard, E.; Drozdova, O.Yu; Lapitskiy, S.A.; Bychkov, A.Yu; Pokrovsky, O.S. Transformation of organo-ferric peat colloids by a heterotrophic bacterium. Geochim. Cosmochim. Acta 2017, 205, 313-330.

(28) Oleinikova, O.V.; Drozdova, O.Yu; Lapitskiy, S.A.; Demin, V.V.; Bychkov, A.Yu; Pokrovsky, O.S. Dissolved organic matter degradation by sunlight coagulates organo-mineral colloids and produces low-molecular weight fraction of metals in boreal humic waters. Geochim. Cosmochim. Acta 2017, 211, 97-114.

(29) Beard, B.L.; Johnson, C.M.; Cox, L.; Sun, H.; Nealson, K.H.; Aguilar, C. Iron isotope biosignatures. Science 1999, 285 (5435), 1889-1892.

(30) Mulholland, D.S.; Poitrasson, F.; Shirokova, L.S.; Gonzalez, A.; Pokrovsky, O.S.; Boaventura, G.R.; Vieira, L.C. Iron isotope fractionation during $\mathrm{Fe}(\mathrm{II})$ and Fe(III) adsorption on cyanobacteria. Chem. Geol. 2015, 400, 24-33.

(31) Swanner, E.D.; Bayer, T.; Wu, W.; Hao, L.; Obst, M.; Sundman, A.; Byrne, J.M.; Michel, F.M.; Kleinhanns, I.C.; Kappler, A.; Schoenberg, R. Iron isotope fractionation during Fe(II) oxidation mediated by the oxygen-producing marine cyanobacterium Synechococcus PCC 7002. Environ. Sci. Technol. 2017, 51 (9), 4897-4906.

(32) Swanner, E.D.; Wu, W.; Schoenberg, R.; Byrne, J.; Michel, F.M.; Pan, Y.; Kappler, A. Fractionation of $\mathrm{Fe}$ isotopes during $\mathrm{Fe}(\mathrm{II})$ oxidation by a marine photoferrotroph is controlled by the formation of organic Fe-complexes and colloidal Fe fractions. Geochim. Cosmochim. Acta 2015, $165,44-61$.

(33) Amor, M.; Busigny, V.; Louvat, P.; Tharaud, M.; Gelabert, A.; Cartigny, P.; Carlut, J.; Isambert, A.; Durand-Dubief, M.; Ona-Nguema, G.; Alphandery, E.; Chebbi, I.; Guyot, F. Iron uptake and magnetite biomineralization in the magnetotactic bacterium Magnetospirillum magneticum strain AMB-1: An iron isotope study. Geochim. Cosmochim. Acta 2018, 232, 225-243.

(34) Zhou, Z.; Latta, D.E.; Noor, N.; Thompson, A.; Borch, T.; Scherer, M.M. Fe(II)-catalyzed transformation of organic matter-ferrihydrite coprecipitates: A closer look using $\mathrm{Fe}$ isotopes. Environ. Sci. Technol. 2018, 52, 11142-11150.

(35) Brantley, S.L.; Liermann, L.J.; Guynn, R.L.; Anbar, A.; Icopini, G.A.; Barling, J. Fe isotopic fractionation during mineral dissolution with and without bacteria. Geochim. Cosmochim. Acta 2004, 68, 3189-3204.

(36) Crosby, H.A.; Johnson, C.M.; Roden, E.E.; Beard, B.L. Coupled Fe(II)-Fe(III) electron and atom exchange as a mechanism for $\mathrm{Fe}$ isotope fractionation during dissimilatory iron oxide reduction. Environ. Sci. Technol. 2005, 39, 6698-6704.

(37) Ilina, S.M.; Poitrasson, F.; Lapitskiy, S.A.; Alekhin, Yu.V.; Viers, J.; Pokrovsky, O.S. Extreme iron isotope fractionation between colloids and particles of boreal and temperate organicrich waters. Geochim. Cosmochim. Acta 2013, 101, 96-111.

(38) Kopácek, J.; Maresova, M.; Norton, S.A.; Porcal, P.; Vesely, J. Photochemical source of metals for sediments. Environ. Sci. Technol. 2006, 40, 4455-4459.

(39) Wu, L.L.; Beard, B.L.; Roden, E.E.; Johnson, C.M. Stable iron isotope fractionation between aqueous Fe(II) and hydrous ferric oxide. Environ. Sci. Technol. 2011, 45 (5), 1847-1852. 
(40) Skulan, J.L.; Beard, B.L.; Johnson, C.M. Kinetic and equilibrium Fe isotope fractionation between aqueous Fe(III) and hematite. Geochim. Cosmochim. Acta 2002, 66, 2995-3015.

(41) Frierdich, A.J.; Beard, B.L.; Reddy, T.R.; Scherer, M.M.; Johnson, C.M. Iron isotope fractionation between aqueous $\mathrm{Fe}(\mathrm{II})$ and goethite revisited: New insights based on a multi-direction approach to equilibrium and isotopic exchange rate modification. Geochim. Cosmochim. Acta 2014, 139, 383-398.

(42) Sun, R.Y.; Wang, B.L. Iron isotope fractionation during uptake of ferrous ion by phytoplankton. Chem. Geol. 2018, 481, 65-73.

(43) Vasyukova, E.V.; Pokrovsky, O.S.; Viers, J., Oliva, P., Dupré, B., Martin, F., Candadaup, F. Trace elements in organic- and iron-rich surficial fluids of the boreal zone: Assessing colloidal forms via dialysis and ultrafiltration. Geochim. Cosmochim. Acta 2010, 74, 449-468.

(44) González, A.G.; Pokrovsky, O.S.; Jiminez-Villacorta, F.; Shirokova, L.S.; Santana-Casiano, J.M.; González-Davila, M.; Emnova, E.E. Iron adsorption onto soil and aquatic bacteria: XAS structural study. Chem. Geol. 2014, 372, 32-45

(45) Viollier, E.; Inglett, P.W.; Hunter, K.; Roychoudhury, A.N.; Van Cappellen, P. The ferrozine method revisited: $\mathrm{Fe}(\mathrm{II}) / \mathrm{Fe}(\mathrm{III})$ determination in natural waters. Appl. Geochem. 2000, 15 (6), 785790.

(46) Mulholland, D.S.; Poitrasson, F.; Boaventura, G.R.; Allard, T.; Vieira, L.C.; Santos, R.V.; Mancini, L.; Seyler, P. Insights into iron sources and pathways in the Amazon River provided by isotopic and spectroscopic studies. Geochim. Cosmochim. Acta 2015, 150, 142-159.

(47) Ilina, S.M.; Drozdova, O.Y.; Lapitsky, S.A.; Alekhin, Yu.V.; Demin, V.V.; Zavgorodnaya, Yu.A.; Shirokova, L.S.; Viers, J.; Pokrovsky, O.S. Size fractionation and optical properties of dissolved organic matter in the continuum soil solution-bog-river and terminal lake of a boreal watershed. Organic Geochem. 2014, 66, 14-24.

(48) Gustafsson, J. Visual MINTEQ ver. 3.1. http://vminteq.lwr.kth.se, 2014, assessed 8.02.2019.

(49) Poitrasson F.; Freydier, R. Heavy iron isotope composition of granites determined by high resolution MC-ICP-MS. Chem. Geol. 2005, 222, 132-147.

(50) Mulholland, D.S.; Poitrasson, F.; Boaventura, G.R. Effect of different water storage procedures on the dissolved Fe concentration and isotopic composition of chemically contrasted waters from the Amazon River Basin. Rapid Comm. Mass Spectr. 2015, 29, 2102-2108.

(51) Kafantaris, F.C.A.; Borrok, D.M. Zinc isotope fractionation during surface adsorption and intracellular incorporation by bacteria. Chem. Geol. 2014, 366, 42-51.

(52) Croal, L.R.; Johnson, C.M.; Beard, B.L.; Newman, D.K. Iron isotope fractionation by Fe(II)oxidizing photoautotrophic bacteria. Geochim. Cosmochim. Acta 2004, 68, 1227-1242.

(53) Bullen, T.D.; White, A.F.; Childs, C.W.; Vivit, D.V.; Schulz, M.S. Demonstration of significant abiotic iron isotope fractionation in nature. Geology 2001, 29, 699-702.

(54) Beard, B.L.; Handler, R.M.; Scherer, M.M.; Wu, L.; Czaja, A.D.; Heimann, A.; Johnson, C.M. Iron isotope fractionation between aqueous ferrous iron and goethite. Earth Planet. Sci. Lett. 2010, 295 (1-2), 241-250.

(55) Dideriksen, K.; Baker, J.A.; Stipp, S.L.S. Equilibrium Fe isotope fractionation between inorganic aqueous Fe(III) and the siderophore complex, Fe(III)-desferrioxamine B. Earth Planet. Sci. Lett. 2008, 269, 280- 290.

(56) Morgan, J. L.; Wasylenki, L. E.; Nuester, J.; Anbar, A. D. Fe isotope fractionation during equilibration of Fe-organic complexes. Environ. Sci. Technol. 2010, 44, 6095-6101.

(57) Chupakova, A.A.; Chupakov, A.V.; Neverova, N.V.; Shirokova, L.S.; Pokrovsky, O.S. Photodegradation of river dissolved organic matter and trace metals in the largest European Arctic estuary. Sci. Total Environ. 2018, 622-623, 1343-1352.

(58) Barbeau, K.; Rue, E.; Bruland, K.; Butler A. Photochemical cycling of iron in the surface ocean mediated by microbial iron (III)-binding ligands. Nature 2001, 413, 409-413.

(59) Welch, S.A.; Beard, B.L.; Johnson, C.M.; Braterman, P.S. Kinetic and equilibrium Fe isotope fractionation between aqueous $\mathrm{Fe}(\mathrm{II})$ and $\mathrm{Fe}(\mathrm{III})$. Geochim. Cosmochim. Acta 2003, 67(22), 4231-4250. 
(60) Balci, N.; Bullen, T.D.; Witte-Lien, K.; Shanks, W.C.; Motelica, M.; Mandernack, K.W. Iron isotope fractionation during microbially stimulated $\mathrm{Fe}(\mathrm{II})$ oxidation and $\mathrm{Fe}(\mathrm{III})$ precipitation. Geochim. Cosmochim. Acta 2006, 70, 622-639.

(61) Teutsch, N.; Von Gunten, U.; Porcelli, D.; Cirpka, O.A.; Halliday, A.N. Adsorption as a cause for iron isotope fractionation in reduced groundwater. Geochim. Cosmochim. Acta 2005, 69(17), 4175-4185.

(62) Johnson, C.M.; Beard, B.L.; Roden, E.E.; Newman, D.K.; Nealson, K.H. Isotopic constraints on biogeochemical cycling of Fe. Rev. Mineral. Geochem. 2004, 55, 359-408.

(63) Reddy, T.R.; Frierdich, A.J.; Beard, B.L.; Johnson, C.M. The effect of pH on stable iron isotope exchange and fractionation between aqueous Fe(II) and goethite. Chem. Geol. 2015, 397, $118-127$.

(64) Handler, R.M.; Beard, B.L.; Johnson, C.M.; Scherer, M.M. Atom exchange between aqueous Fe(II) and goethite: an Fe isotope tracer study. Environ. Sci. Technol. 2009, 43(4), 11021107.

(65) Chanda, P., Zhou, Z., Latta, D., Scherer, M., Beard, B., Johnson, C. Effect of organic C on stable $\mathrm{Fe}$ isotopic fractionation between aqueous $\mathrm{Fe}(\mathrm{II})$ and ferrihydrite. Goldschmidt Abstracts, 2018, 365, https://goldschmidt.info/2018/abstracts/abstractView?id=2018003824.

(66) Anesio, A.M.; Granéli, W. Increased photoreactivity of DOC by acidification: Implication for the carbon cycle in humic lakes. Limnol. Oceanogr. 2003, 48, 735-744.

(67) Gao, H.; Zepp, R.G. Factors influencing photoreactions of dissolved organic matter in a coastal river of the southeastern United States. Environ. Sci. Technol. 1998, 32, 2940-2946.

(68) Wang, Y.; Xiang, W.; Yang, W.; Yan, S.; Bao, Z.; Liu, Y. Photo-stability of iron-phenolic complexes derived from peatland upon irradiation in waters under simulated sunlight. Chem. Geol. 2018, 485, 14-23.

(69) Helms, J.R.; Mao, J.; Schmidt-Rohr, K.; Abdulla, H.; Mopper, K. Photochemical flocculation of terrestrial dissolved organic matter and iron. Geochim. Cosmochim. Acta 2013, 121, 398-413.

(70) Catrouillet, C.; Davranche, M.; Dia, A.; Bouhnik-Le Coz, M.; Marsac, R.; Pourret, O.; Gruau, G. Geochemical modeling of Fe(II) binding to humic and fulvic acids. Chemical Geol. 2014, 372, 109-118.

(71) Dauphas, N.; John, S.G.; Rouxel, O. Iron isotope systematics. Rev. Mineral. Geochem. 2017, $82,415-510$.

(72) Drozdova, O.Yu.; Ilina, S.M.; Lapitsky, S.A. The transformation of dissolved organic matter in the soil water - bog - stream - terinal lake continuum of a boreal watershed (Northern Karelia), in: Pokrovsky, O.S., Shirokova, L.S., eds. Dissolved Organic Matter (DOM): Properties, Applications and Behavior, Nova Publishers, N.Y., 2017, pp. 115-133. 
Table 1. Measured $\mathrm{pH}, \mathrm{DOC}, \mathrm{Fe}$ concentrations and isotopic ratios, relative to IRMM-14, during bio-and photo-degradation experiments. Note that the DOC in biodegradation experiments of stream water slightly increased due to cell lysis and exometabolite production. The standard error was calculated using the Student's t factor: $\mathrm{SE}=(\mathrm{t} \times \mathrm{SD}) / \sqrt{ } \mathrm{N}$, where $\mathrm{N}$ is the number of measurements.

\begin{tabular}{|c|c|c|c|c|c|c|c|c|c|c|c|}
\hline \multicolumn{12}{|c|}{ Bio-degradation $\left(1 \mathrm{~g}_{\mathrm{wet}} / \mathrm{L}\right.$ of Pseudomonas aureofaciens $)$} \\
\hline \multirow[b]{2}{*}{ hrs } & \multicolumn{5}{|c|}{ Fen water $\mathrm{ZPBL}<0.22 \mu \mathrm{m}$} & \multirow[b]{2}{*}{ hrs } & \multicolumn{5}{|c|}{ Stream water KAR-1 $<0.22 \mu \mathrm{m}$} \\
\hline & pH & $\begin{array}{l}\text { DOC, } \\
\text { mg L }^{-1}\end{array}$ & $\begin{array}{c}\mathrm{Fe}, \\
\mu \mathrm{g} \mathrm{L}^{-1}\end{array}$ & $\begin{array}{l}\mathrm{Fe}(\mathrm{II}), \\
\mu \mathrm{g} \mathrm{L^{-1 }}\end{array}$ & $\begin{array}{c}\delta^{57} \mathrm{Fe} \\
\pm 2 \mathrm{SE}, \% 0\end{array}$ & & pH & $\begin{array}{l}\text { DOC, } \\
\text { mg L }^{-1}\end{array}$ & $\underset{\mu \mathrm{ge} \mathrm{L}^{-1}}{\mathrm{Fe}}$ & $\begin{array}{l}\mathrm{Fe}(\mathrm{II}), \\
\mu \mathrm{g} \mathrm{L^{-1 }}\end{array}$ & $\begin{array}{c}\delta^{57} \mathrm{Fe} \\
\pm 2 \mathrm{SE}, \%\end{array}$ \\
\hline 0 & 4.9 & 37.4 & $2470 \pm 45$ & $645 \pm 20$ & $1.06 \pm 0.05$ & 0 & 6.6 & 12.4 & $180 \pm 10$ & $30 \pm 20$ & $2.87 \pm 0.07$ \\
\hline 1 & 5.2 & 37.0 & $1690 \pm 20$ & $620 \pm 20$ & $0.86 \pm 0.07$ & 1 & 6.4 & 13.6 & $115 \pm 7$ & $<\mathrm{LOQ}^{*}$ & $2.54 \pm 0.06$ \\
\hline 8 & 5.4 & 35.8 & $1520 \pm 20$ & $290 \pm 10$ & $0.85 \pm 0.12$ & 8 & 6.4 & 13.0 & $82 \pm 10$ & $<\mathrm{LOQ}^{*}$ & $2.68 \pm 0.16$ \\
\hline 22 & 5.7 & 34.8 & $1365 \pm 15$ & no data & $0.88 \pm 0.07$ & 22 & 6.7 & 14.0 & $63 \pm 3$ & $<\mathrm{LOQ}^{*}$ & $3.21 \pm 0.15$ \\
\hline 30 & 5.8 & 26.6 & $1290 \pm 5$ & $145 \pm 5$ & $0.99 \pm 0.10$ & 50 & 7.0 & 14.1 & $56 \pm 2$ & $<\mathrm{LOQ}^{*}$ & $3.26 \pm 0.13$ \\
\hline 50 & 5.8 & 23.3 & $1197 \pm 5$ & $120 \pm 10$ & $1.03 \pm 0.05$ & 100 & 7.2 & 15.2 & $50 \pm 2$ & $<\mathrm{LOQ}^{*}$ & no data \\
\hline 100 & 6.1 & 25.2 & $1054 \pm 5$ & $84 \pm 5$ & $1.04 \pm 0.04$ & & & & & & \\
\hline \multicolumn{12}{|c|}{ Sunlight exposure } \\
\hline hrs & \multicolumn{5}{|c|}{ Fen water $\mathrm{ZPBL}<0.22 \mu \mathrm{m}$} & hrs & \multicolumn{5}{|c|}{ Stream water KAR-1 $<0.22 \mu \mathrm{m}$} \\
\hline 0 & 5.4 & 38.7 & $4310 \pm 100$ & $840 \pm 50$ & $0.25 \pm 0.07$ & 0 & 7.2 & 11.9 & $208 \pm 20$ & $50 \pm 20$ & $1.59 \pm 0.05$ \\
\hline 100 & 5.1 & 20.3 & $1840 \pm 400$ & $770 \pm 170$ & $-0.8 \pm 0.38$ & 110 & 6.8 & 10.4 & $193 \pm 25$ & $60 \pm 25$ & $1.75 \pm 0.2$ \\
\hline 200 & 5.3 & 18.7 & $915 \pm 30$ & $450 \pm 10$ & $-2.63 \pm 0.03$ & 250 & 6.7 & 8.2 & $175 \pm 25$ & $15 \pm 5$ & $2.1 \pm 0.12$ \\
\hline hrs & \multicolumn{5}{|c|}{ Fen water $\mathrm{ZPBL}<10 \mathrm{kDa}$} & hrs & \multicolumn{5}{|c|}{ Stream water $\mathrm{KAR}-1<\mathbf{1 0} \mathrm{kDa}$} \\
\hline 0 & 5.3 & 26.5 & $1125 \pm 50$ & $620 \pm 20$ & $0.19 \pm 0.02$ & 0 & 6.8 & 10.2 & $35 \pm 5$ & $20 \pm 10$ & $2.93 \pm 0.06$ \\
\hline 100 & 5.2 & 18.7 & $1000 \pm 50$ & $510 \pm 20$ & $-1.98 \pm 0.13$ & 110 & 6.9 & 10.0 & $49 \pm 10$ & $30 \pm 20$ & $1.95 \pm 0.06$ \\
\hline 200 & 5.3 & 17.9 & $945 \pm 50$ & $470 \pm 30$ & $-2.49 \pm 0.15$ & 250 & 6.8 & 8.1 & $14 \pm 2$ & $<\mathrm{LOQ}^{*}$ & $1.89 \pm 0.07$ \\
\hline hrs & \multicolumn{5}{|c|}{ Fen water $\mathrm{ZPBL}<\mathbf{1} \mathrm{kDa}$} & \multirow{4}{*}{\multicolumn{6}{|c|}{$*$ Limit of quantification }} \\
\hline 0 & 5.6 & 10.6 & $200 \pm 20$ & $70 \pm 10$ & $-0.18 \pm 0.03$ & & & & & & \\
\hline 100 & 5.3 & 11.5 & $560 \pm 30$ & $300 \pm 100$ & $-2.34 \pm 0.11$ & & & & & & \\
\hline 200 & 5.4 & 16.8 & $620 \pm 30$ & $340 \pm 100$ & $-2.43 \pm 0.12$ & & & & & & \\
\hline
\end{tabular}




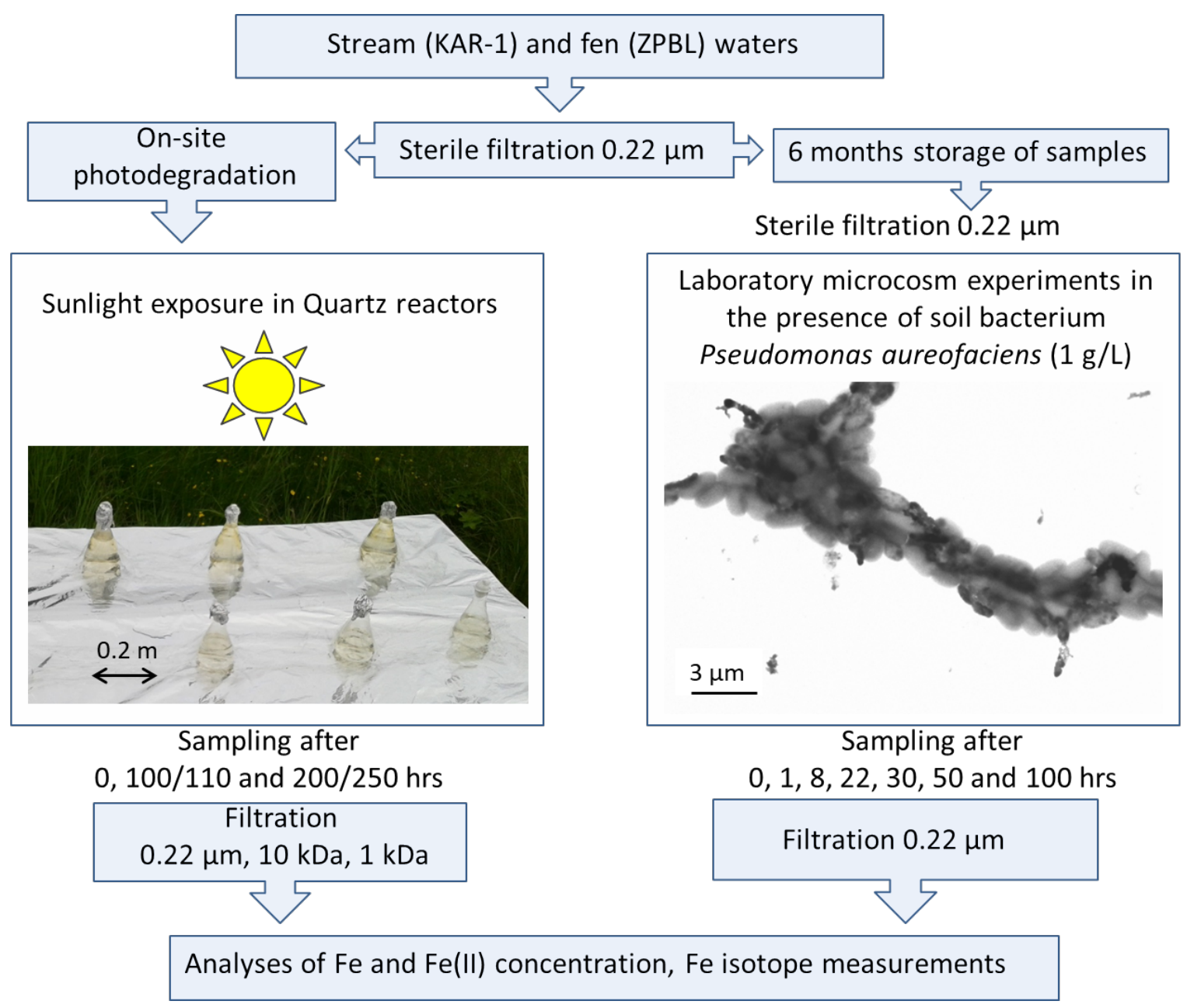

717 Fig. 1. Conceptual scheme of experiments (run in duplicates): a photo of quartz reactors exposed to sunlight and a Transmission Electron Microscopy (TEM) image of bacterial cells with precipitated $\mathrm{Fe}$ hydroxides. The photodegradation experiments were performed on-site, immediately after water sampling and sterile filtration. The biodegradation experiments required sterile laboratory environments and were run after 6 months of water storage. The biodegradation experiments included only $<0.22 \mu \mathrm{m}$ filtration after sampling. In photodegradation experiments, the stream water was processed for the $<0.22 \mu \mathrm{m}$ and the $<$ $10 \mathrm{kDa}$ filtration and the fen water was filtered through $0.22 \mu \mathrm{m}, 10 \mathrm{kDa}$ and $1 \mathrm{kDa}$. 

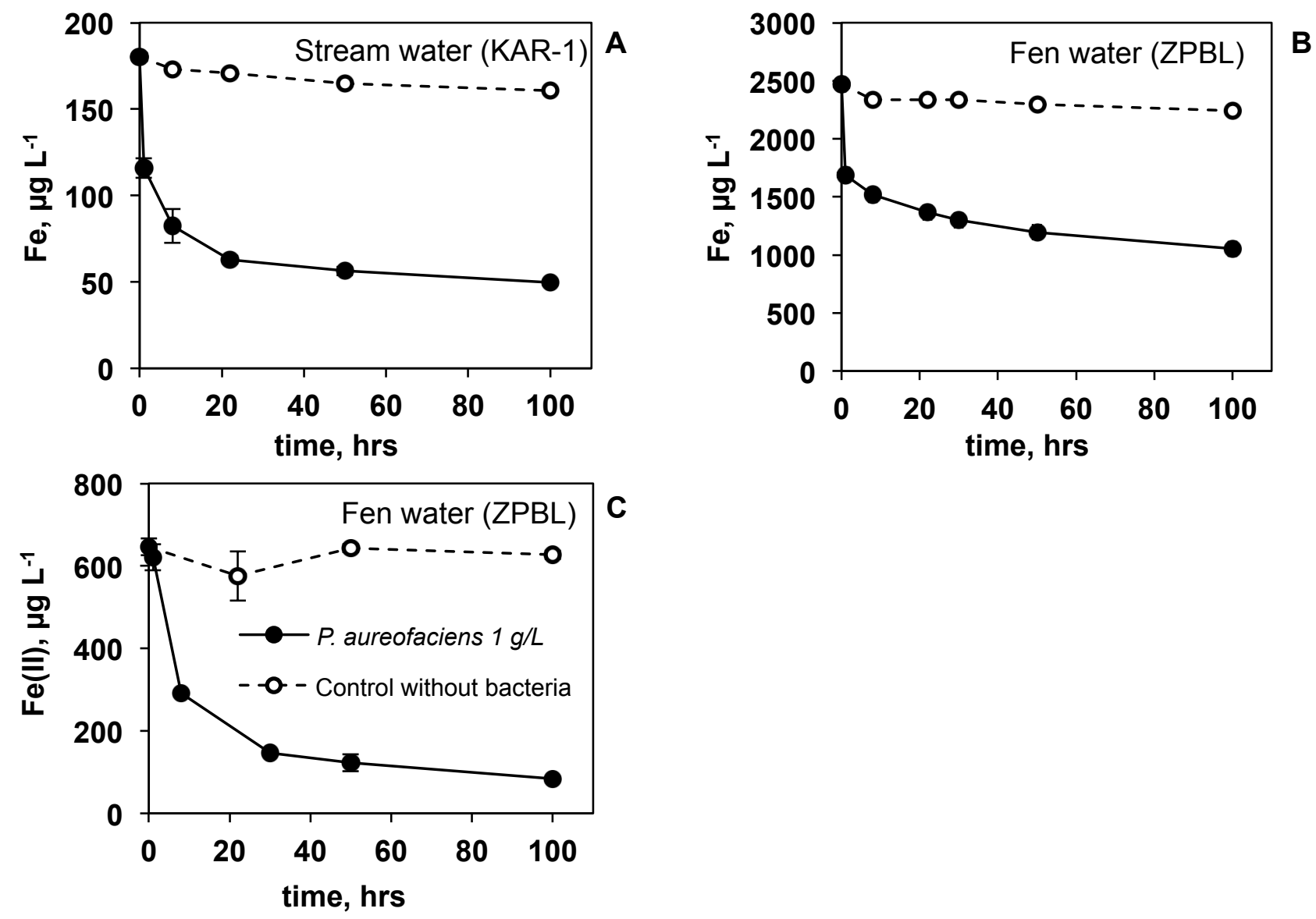

726 Fig. 2. Evolution of total dissolved $\mathrm{Fe}$ concentration during biodegradation experiments of stream (A) and fen (B) water. (C): Fe(II) concentration evolution in the fen water during biodegradation. The error bars of biotic experiments represent $1 \mathrm{SD}$ of duplicates. In most cases, they are smaller than the symbol size. Bacterial experiments are shown by solid circles and bacteria-free control is represented by open circles for all three panels as indicated in (C). A 10 to $12 \%$ decrease of Fe concentration in the bacteria-free control experiment may be due to precipitation of small amount of $\mathrm{Fe}(\mathrm{III})$ hydroxide. 

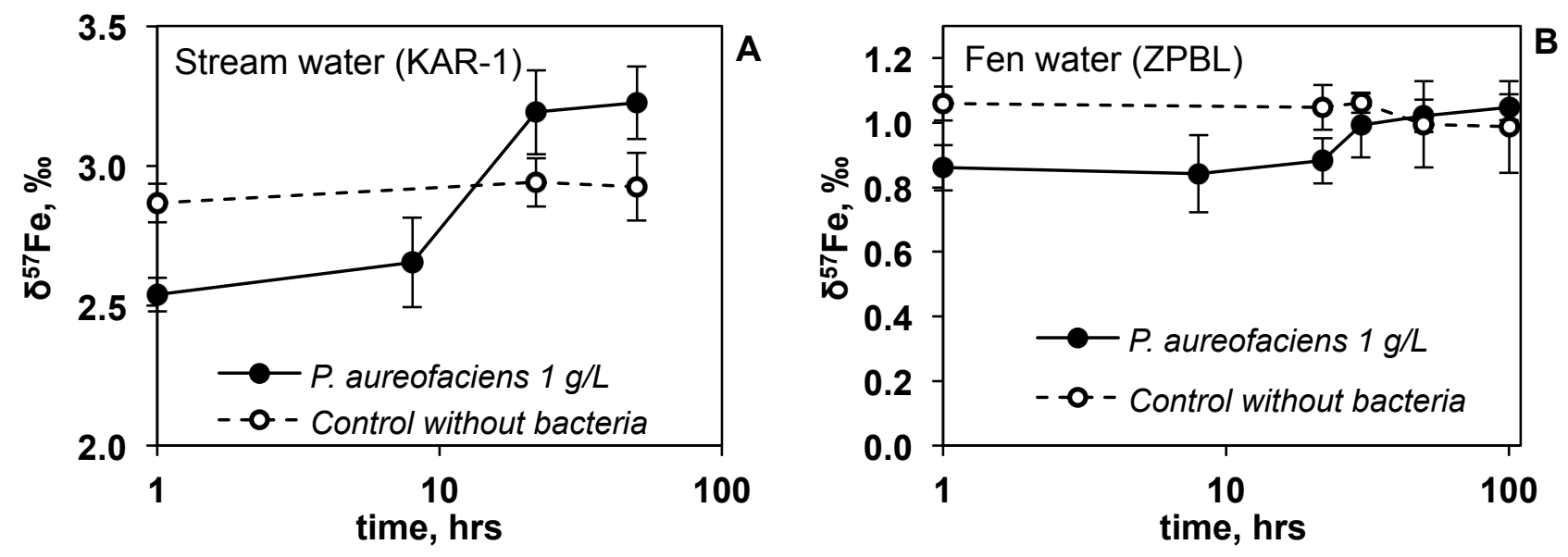

739

740 Fig. 3. Evolution of isotopic ratios $\delta^{57}$ Fe during biodegradation experiments of stream (A) and fen 741 (B) water. Note log scale for time axis.. 

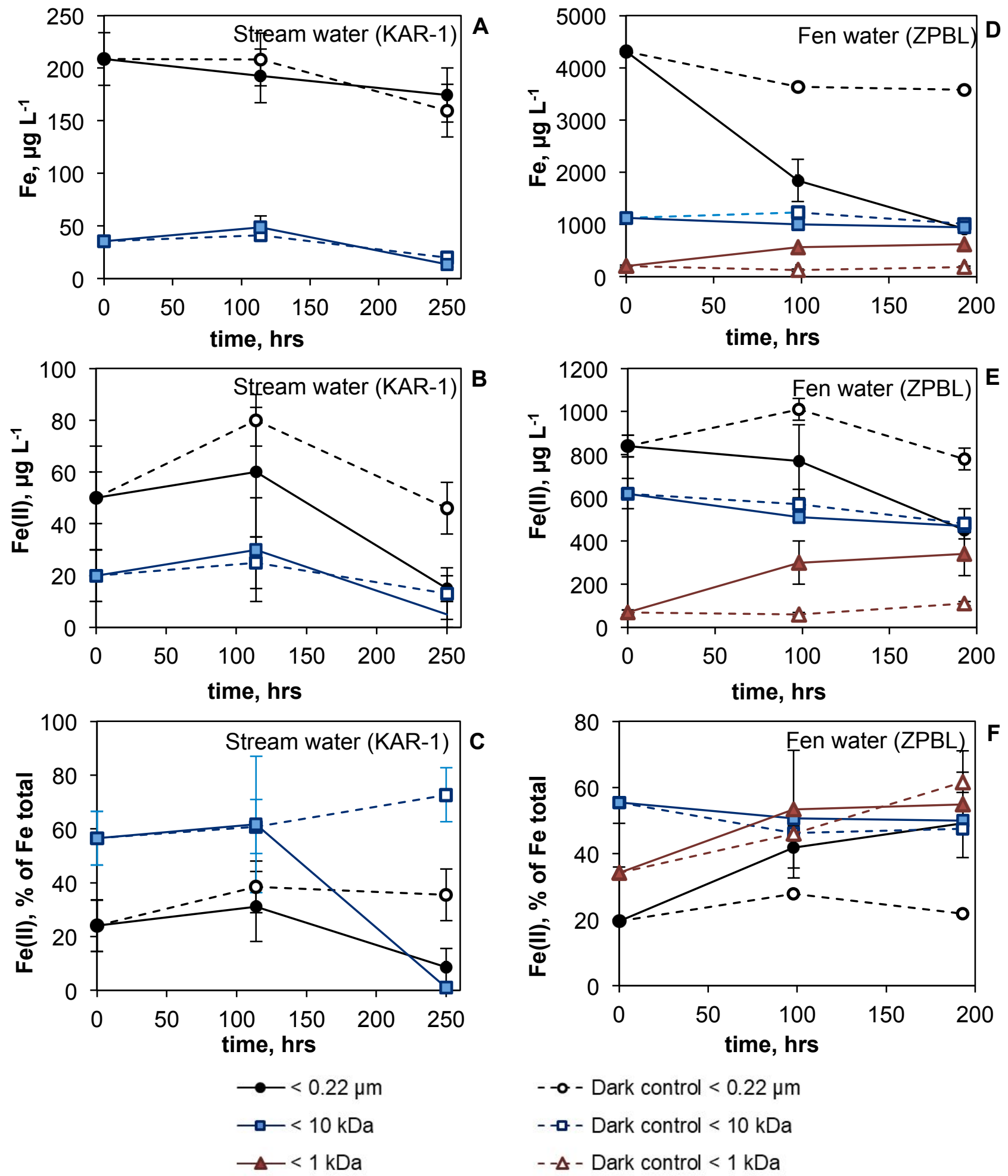

$$
\begin{aligned}
& --\mathrm{-} \text { - Dark control }<0.22 \mu \mathrm{m} \\
& --\mathrm{-}-\text { Dark control }<10 \mathrm{kDa} \\
& --\Delta-\text { Dark control }<1 \mathrm{kDa}
\end{aligned}
$$

Fig. 4. Evolution of $\mathrm{Fe}_{\text {tot }}$ and $\mathrm{Fe}(\mathrm{II})$ concentration during photodegradation experiments of stream $(\mathbf{A}, \mathbf{B}, \mathbf{C})$ and fen $(\mathbf{D}, \mathbf{E}$ and $\mathbf{F})$ water in quartz reactors. Note a drop in $\mathrm{Fe}_{\text {tot }}$ and $\mathrm{Fe}(\mathrm{II})$

754 concentration of the $<0.22 \mu \mathrm{m}$ dark control at 200 and $250 \mathrm{~h}$ not observed in previously stored 755 samples in biodegradation experiments (Fig. 2), which may be due to partial precipitation fo Fe(III) 756 hydroxide in freshly sampled natural water upon storage. 

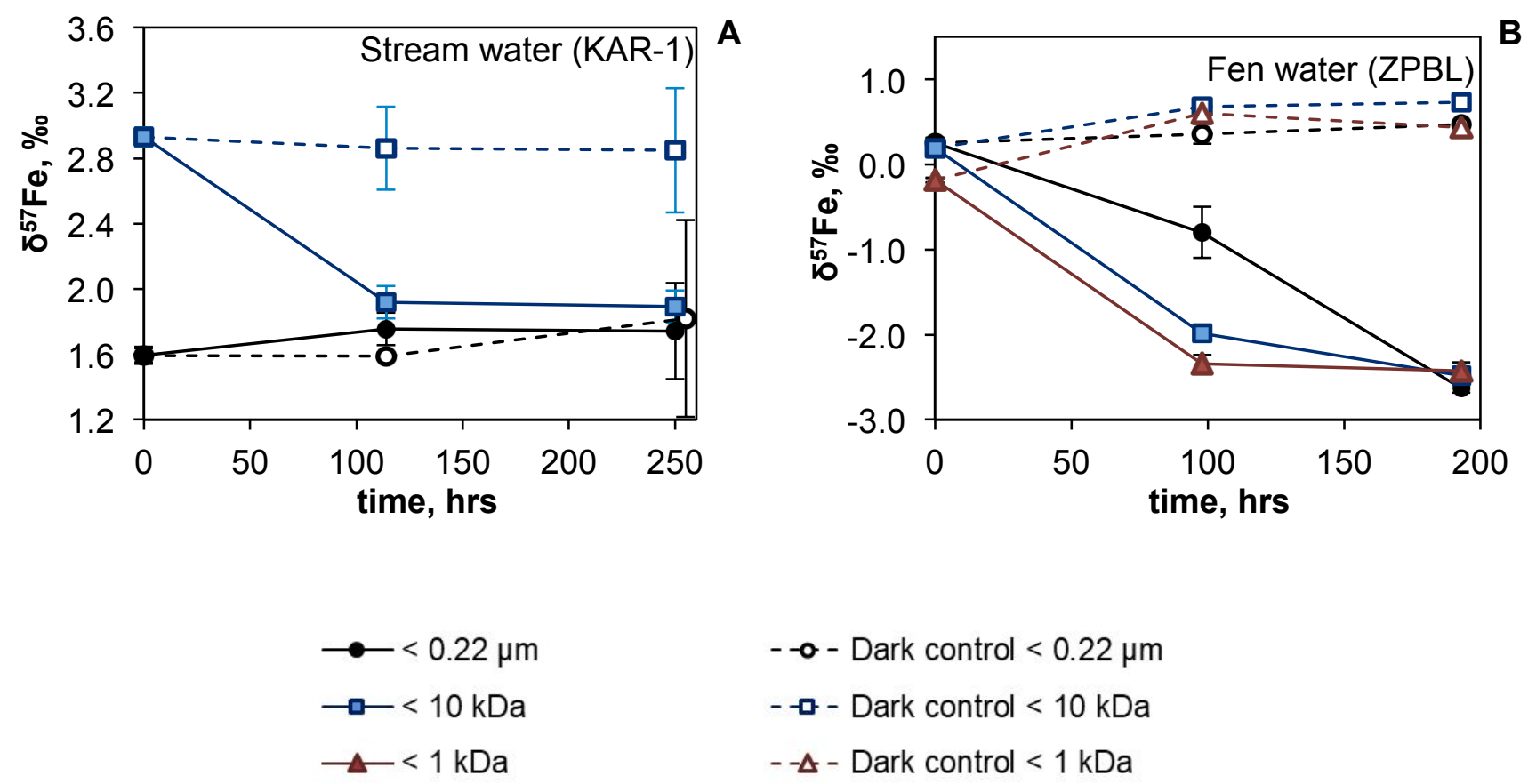

- - - - Dark control $<0.22 \mu \mathrm{m}$

- - - Dark control $<10 \mathrm{kDa}$

$--\Delta-$ Dark control $<1 \mathrm{kDa}$

760 Fig 5. Evolution of isotopic ratios $\delta^{57} \mathrm{Fe}$ during photodegradation experiments of stream (A) and fen

(B) water. There is a clear decrease in $\delta^{57} \mathrm{Fe}$ value in all fractions of photodegraded samples of fen water, but this decrease is only pronounced for the $<10 \mathrm{kDa}$ fraction of stream water. Note that a weak increase in $\delta^{57} \mathrm{Fe}$ for the $<0.22 \mu \mathrm{m}$ dark control in KAR-1 is within the uncertainty of replicates. An increase in $\delta^{57} \mathrm{Fe}$ for the $<1 \mathrm{kDa}$ and $<10 \mathrm{kDa}$ dark control of fen waters is due to Fe loss of these unstable, freshly sampled waters. 


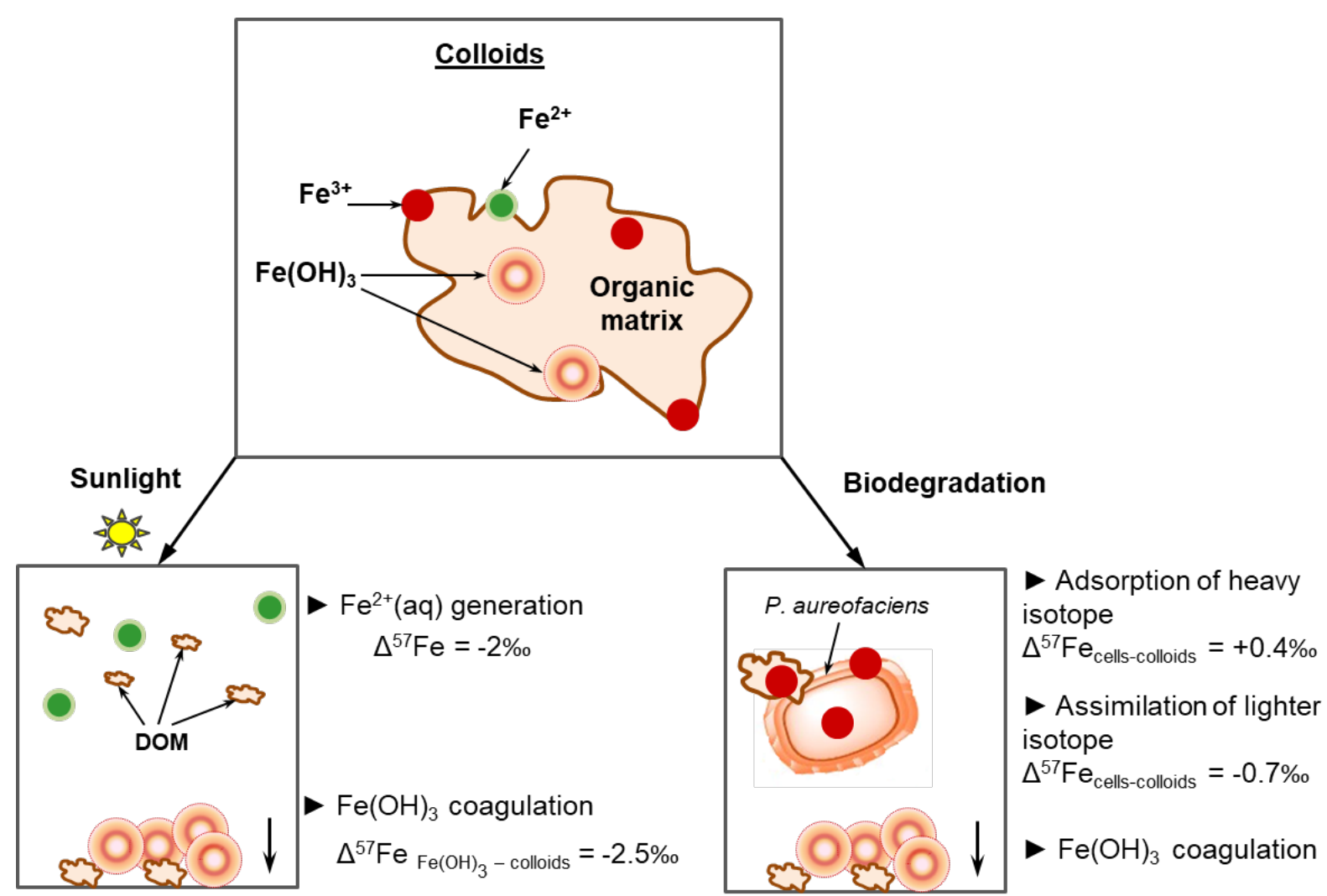

772 Fig. 6. Cartoon of $\mathrm{Fe}$ isotope fractionation under sunlight-induced transformation (left) and

773 biodegradation (right) of organic and organo-ferric colloids (1 kDa - $0.22 \mu \mathrm{m})$. Live heterotrophic $P$.

774 aureofaciens bacteria adsorb heavier and assimilate lighter Fe isotopes. Sunlight irradiation

775 generates isotopically light $\mathrm{Fe}(\mathrm{II})$ in low molecular weight $(<1 \mathrm{kDa})$ fraction and produces heavy

776 isotope enrichment in particulate fraction relative to total dissolved $(<0.22 \mu \mathrm{m})$ form. After bio- or

777 photo-degradation of organic matter which constitutes organo-ferric colloids, the liberation of Fe(III)

778 ions and precipitation of Fe(III) hydroxide occur. This removes heavier isotopes from solution into

779 the solid phase. Altogether, bio-and photodegradation of organo-ferric colloids can produce very $\mathrm{Fe}$ )

780 large, from -2 to $+3 \%$ isotopic variations $\left(\delta^{57} \mathrm{Fe}\right)$ in boreal humic waters. 
798 Measured pH, DOC, Fe concentrations and isotopic ratios in control reactors used in bio-and 799 photo-degradation experiments; results of vMinteq calculation of $\mathrm{Fe}$ (II) and $\mathrm{Fe}$ (III) speciation 800 in experimental solutions

801 


\section{SUPPORTING INFORMATION:}

Measured pH, DOC, Fe concentrations and isotopic ratios in control reactors used in bio-and photo-degradation experiments; results of vMinteq calculation of $\mathrm{Fe}$ (II) and $\mathrm{Fe}$ (III) speciation in experimental solutions

Table S1. Measured pH, DOC, Fe concentrations and isotopic ratios, relative to IRMM-14, in control reactors used in bio-and photo-degradation experiments. Note that abiotic $<0.22 \mu \mathrm{m}$ controls of biodegradation experiments were more stable in terms of both $[\mathrm{Fe}]$ and $\delta^{57} \mathrm{Fe}$ than the dark controls of photodegradation experiments. Freshly sampled natural water used for photodegradation experiments could be subjected to certain transformation, re-equilibration and even coagulation of Fe and DOC. In contrast, aged filtered water was used in biodegradation experiments and it produced more stable pattern of concentration and isotope signature in control reactors.

\begin{tabular}{|c|c|c|c|c|c|c|c|c|c|c|c|}
\hline \multicolumn{12}{|c|}{ Bio-degradation control reactors } \\
\hline \multirow[b]{2}{*}{ hrs } & \multicolumn{5}{|c|}{ Fen water $(\mathrm{ZPBL})<0.22 \mu \mathrm{m}$} & \multirow[b]{2}{*}{ hrs } & \multicolumn{5}{|c|}{ Stream water $($ KAR-1) $<0.22 \mu \mathrm{m}$} \\
\hline & $\mathbf{p H}$ & $\begin{array}{l}\text { DOC, } \\
\text { mg L }^{-1}\end{array}$ & $\begin{array}{c}\mathrm{Fe}, \\
\mu \mathrm{g} \mathrm{L^{-1 }}\end{array}$ & $\begin{array}{l}\mathrm{Fe}(\mathrm{II}), \\
\mu \mathrm{g} \mathrm{L^{-1 }}\end{array}$ & $\begin{array}{c}\delta^{57} \mathrm{Fe} \\
\pm 2 \mathrm{SE}, \% 0\end{array}$ & & pH & $\begin{array}{l}\text { DOC, } \\
\operatorname{mg~L}_{1}^{-}\end{array}$ & $\begin{array}{c}\mathrm{Fe}, \\
\mu \mathrm{g} \mathrm{L^{-1 }}\end{array}$ & $\begin{array}{l}\mathrm{Fe}(\mathrm{II}), \\
\mu \mathrm{g} \mathrm{L^{-1 }}\end{array}$ & $\begin{array}{c}\delta^{57} \mathrm{Fe} \\
\pm 2 \mathrm{SE}, \% \mathrm{o}\end{array}$ \\
\hline 0 & 4.9 & 37.4 & $2470 \pm 45$ & $645 \pm 20$ & $1.06 \pm 0.05$ & 0 & 6.6 & 12.4 & $180 \pm 10$ & $30 \pm 20$ & $2.87 \pm 0.07$ \\
\hline 8 & 4.9 & 35.2 & $2339 \pm 30$ & no data & no data & 8 & 6.6 & 12.2 & $173 \pm 10$ & $20 \pm 10$ & no data \\
\hline 22 & 5.0 & 37.7 & $2335 \pm 30$ & $576 \pm 60$ & $1.05 \pm 0.07$ & 22 & 6.6 & 12.7 & $171 \pm 10$ & no data & $2.94 \pm 0.09$ \\
\hline 30 & 5.1 & 37.0 & $2335 \pm 30$ & no data & $1.06 \pm 0.03$ & 50 & 6.8 & 12.5 & $164 \pm 10$ & $30 \pm 20$ & $2.93 \pm 0.12$ \\
\hline 50 & 5.1 & 36.9 & $2295 \pm 30$ & $643 \pm 10$ & $1 \pm 0.13$ & 100 & 6.9 & 12.1 & $160 \pm 10$ & $<\mathrm{LOQ}^{*}$ & no data \\
\hline 100 & 5.1 & 36.5 & $2242 \pm 30$ & $627 \pm 10$ & $0.99 \pm 0.14$ & & & & & & \\
\hline \multicolumn{12}{|c|}{ Sunlight exposure control reactors } \\
\hline hrs & \multicolumn{5}{|c|}{ Fen water $(\mathrm{ZPBL})<0.22 \mu \mathrm{m}$} & hrs & \multicolumn{5}{|c|}{ Stream water $($ KAR-1) $<0.22 \mu \mathrm{m}$} \\
\hline 0 & 5.4 & 38.7 & $4310 \pm 100$ & $840 \pm 50$ & $0.25 \pm 0.07$ & 0 & 7.2 & 11.9 & $208 \pm 20$ & $50 \pm 20$ & $1.59 \pm 0.05$ \\
\hline 100 & 5.4 & 35.3 & $3630 \pm 50$ & $1010 \pm 70$ & $0.36 \pm 0.14$ & 110 & 7.0 & 11.5 & $210 \pm 30$ & $80 \pm 10$ & $1.59 \pm 0.02$ \\
\hline 200 & 5.3 & 37.0 & $3580 \pm 50$ & $780 \pm 70$ & $0.47 \pm 0.03$ & 250 & 6.8 & 11.8 & $160 \pm 30$ & $46 \pm 10$ & $1.82 \pm 0.60$ \\
\hline hrs & \multicolumn{5}{|c|}{ Fen water $(\mathrm{ZPBL})<10 \mathrm{kDa}$} & hrs & \multicolumn{5}{|c|}{ Stream water $($ KAR-1) $<10$ kDa } \\
\hline 0 & 5.3 & 26.5 & $1125 \pm 50$ & $620 \pm 20$ & $0.19 \pm 0.02$ & 0 & 6.8 & 10.2 & $35 \pm 5$ & $20 \pm 10$ & $2.93 \pm 0.06$ \\
\hline 100 & 5.4 & 25.2 & $1230 \pm 50$ & $570 \pm 70$ & $0.68 \pm 0.01$ & 110 & 7.1 & 8.3 & $40 \pm 5$ & $25 \pm 10$ & $2.86 \pm 0.25$ \\
\hline 200 & 5.4 & 22.2 & $1010 \pm 50$ & $480 \pm 70$ & $0.73 \pm 0.04$ & 250 & 6.8 & 8.4 & $20 \pm 5$ & $15 \pm 10$ & $2.85 \pm 0.38$ \\
\hline hrs & \multicolumn{5}{|c|}{ Fen water $(\mathrm{ZPBL})<1 \mathrm{kDa}$} & \multirow{4}{*}{\multicolumn{6}{|c|}{$*$ Limit of quantification }} \\
\hline 0 & 5.6 & 10.6 & $200 \pm 20$ & $70 \pm 10$ & $-0.18 \pm 0.03$ & & & & & & \\
\hline 100 & 5.8 & 5.3 & $122 \pm 20$ & $60 \pm 10$ & $0.60 \pm 0.07$ & & & & & & \\
\hline 200 & 5.7 & 9.0 & $182 \pm 20$ & $110 \pm 10$ & $0.43 \pm 0.07$ & & & & & & \\
\hline
\end{tabular}


Table S2. Calculated speciation using vMINTEQ of Fe(II) and Fe(III) in $<0.22 \mu \mathrm{m}$ fraction of stream and fen water at the beginning $(0 \mathrm{~h})$ and after $100 \mathrm{~h}$ of biodegradation experiments. FA stands for Fulvic Acid.

\begin{tabular}{|c|c|c|c|c|c|}
\hline \multirow{3}{*}{ Iron } & \multirow{3}{*}{ Species name } & \multicolumn{2}{|c|}{$\begin{array}{c}\text { Fen water (ZPBL) } \\
<0.22 \mu \mathrm{m}\end{array}$} & \multicolumn{2}{|c|}{$\begin{array}{c}\text { Stream water (KAR-1) } \\
<0.22 \mu \mathrm{m}\end{array}$} \\
\hline & & \multicolumn{4}{|c|}{$\%$ of total $\mathrm{Fe}(\mathrm{II})$ or $\mathrm{Fe}(\mathrm{III})$ concentration } \\
\hline & & $0 \mathrm{~h}$ & $100 \mathrm{~h}$ & $0 \mathrm{~h}$ & $100 \mathrm{~h}$ \\
\hline \multirow{3}{*}{$\mathrm{Fe}(\mathrm{II})$} & Free ions & 1.73 & 0 & 0 & 0 \\
\hline & Weakly (electrostatically) bound with FA & 30.33 & 0.01 & 0 & 0 \\
\hline & Complex with FA's carboxylic groups & 67.94 & 99.98 & 99.99 & 100.00 \\
\hline \multirow{2}{*}{$\mathrm{Fe}(\mathrm{III})$} & Complex with FA's carboxylic groups & 26.82 & 6.83 & 0.28 & 0.07 \\
\hline & Complex with FA's phenolic groups & 73.18 & 93.17 & 99.72 & 99.93 \\
\hline
\end{tabular}

Table S3. Speciation of Fe(II) and Fe(III) in $<0.22 \mu \mathrm{m}$ fraction of stream and in $<0.22 \mu \mathrm{m}$ and $<1$ $\mathrm{kDa}$ fractions of fen water at the beginning $(0 \mathrm{~h})$ and after $200-250 \mathrm{~h}$ of sunlight exposure. FA stands for Fulvic Acid.

\begin{tabular}{|c|c|c|c|c|c|c|c|c|}
\hline \multirow{3}{*}{ Iron } & \multirow{2}{*}{ Species name } & \multicolumn{2}{|c|}{$\begin{array}{c}\text { Fen water ZPBL } \\
<0.22 \mu \mathrm{m}\end{array}$} & \multicolumn{2}{|c|}{$\begin{array}{c}\text { Fen water ZPBL } \\
<1 \mathrm{kDa}\end{array}$} & \multicolumn{2}{c|}{$\begin{array}{c}\text { Stream water KAR } \\
<0.22 \mu \mathrm{m}\end{array}$} \\
\cline { 3 - 8 } & & \multicolumn{7}{|c|}{$\%$ of total Fe(II) or Fe(III) concentration } \\
\cline { 2 - 8 } & Fe(II) & $0 \mathrm{~h}$ & $200 \mathrm{~h}$ & $0 \mathrm{~h}$ & $200 \mathrm{~h}$ & $0 \mathrm{~h}$ & $250 \mathrm{~h}$ \\
\cline { 2 - 8 } & $\begin{array}{c}\text { Free ions } \\
\text { (electrostatically) bound } \\
\text { with FA }\end{array}$ & 56.53 & 12.33 & 18.46 & 12.33 & 0 & 0 \\
\cline { 2 - 8 } & $\begin{array}{c}\text { Complex with FA's } \\
\text { carboxylic groups }\end{array}$ & 43.21 & 84.26 & 81.53 & 84.26 & 99.99 & 100.00 \\
\hline \multirow{2}{*}{ Fe(III) } & $\begin{array}{c}\text { Complex with FA's } \\
\text { carboxylic groups }\end{array}$ & 6.60 & 2.20 & 6.60 & 2.20 & 0.11 & 0.32 \\
\cline { 2 - 8 } & $\begin{array}{c}\text { Complex with FA's } \\
\text { phenolic groups }\end{array}$ & 93.40 & 97.81 & 93.40 & 97.81 & 99.89 & 99.68 \\
\hline
\end{tabular}




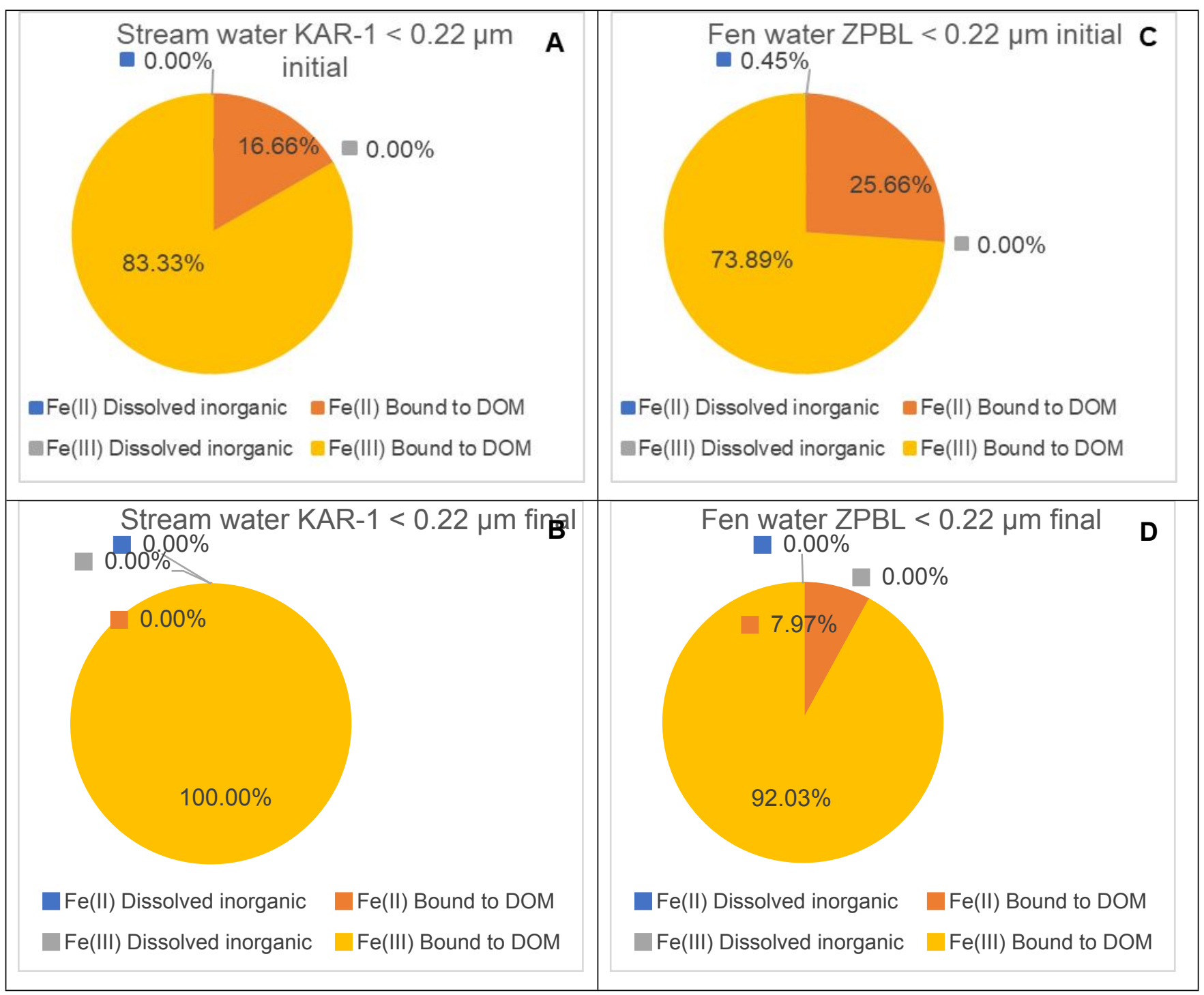

Fig. S1. Results of vMINTEQ speciation calculation for initial $(0 \mathrm{~h})$ and final (100 h) solutions during biodegradation experiments with stream $(\mathbf{A}, \mathbf{B})$ and fen $(\mathbf{C}, \mathbf{D})$ water. 


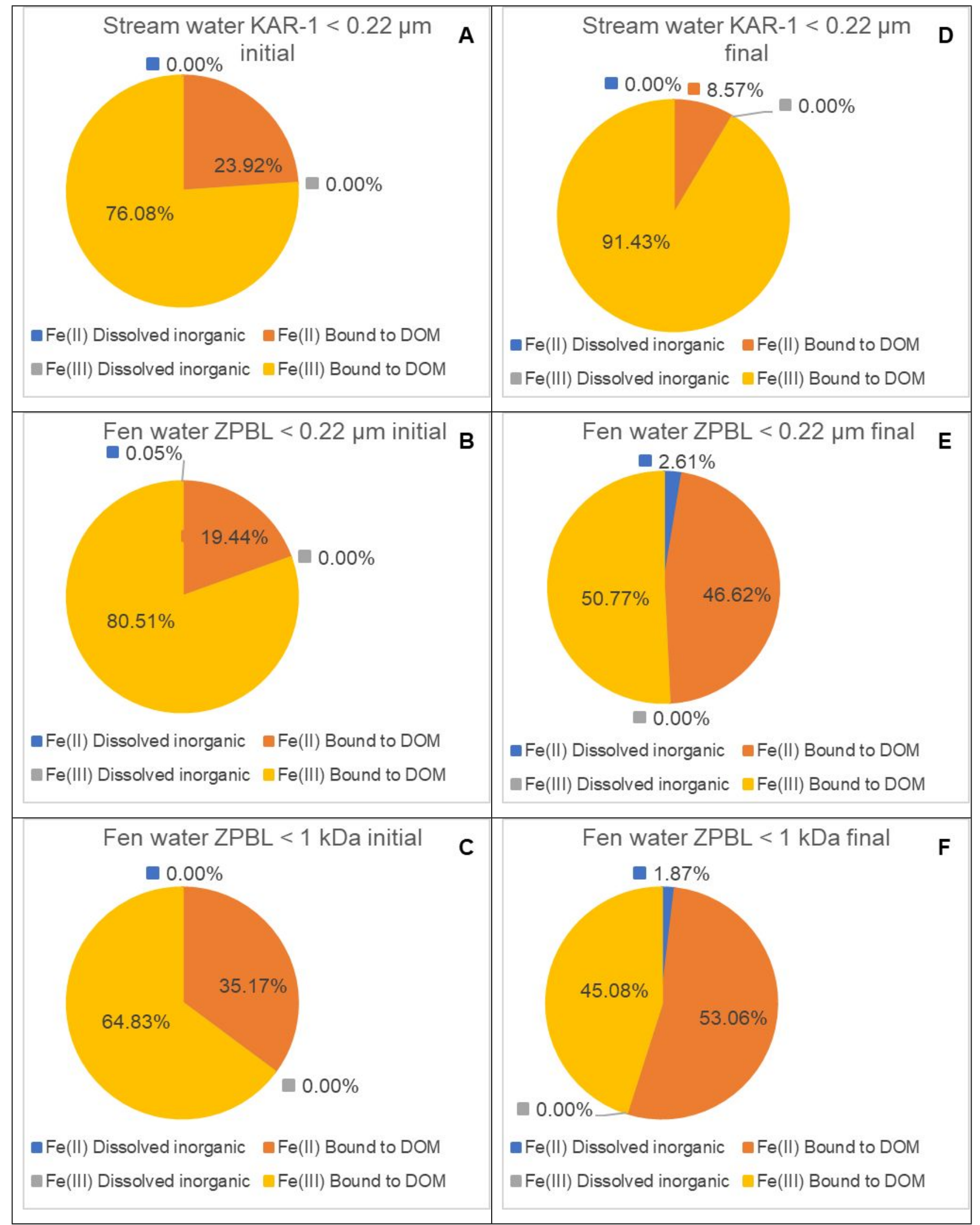

Fig. S2. Results of vMINTEQ speciation calculation for initial $(0 \mathrm{~h})$ and final $(200-250 \mathrm{~h})$ solutions during photodegradation experiments with stream $(\mathbf{A}, \mathbf{D})$ and fen $(\mathbf{B}, \mathbf{C}, \mathbf{E}, \mathbf{F})$ waters. 